INTER NATIONAL MONETARY FUND
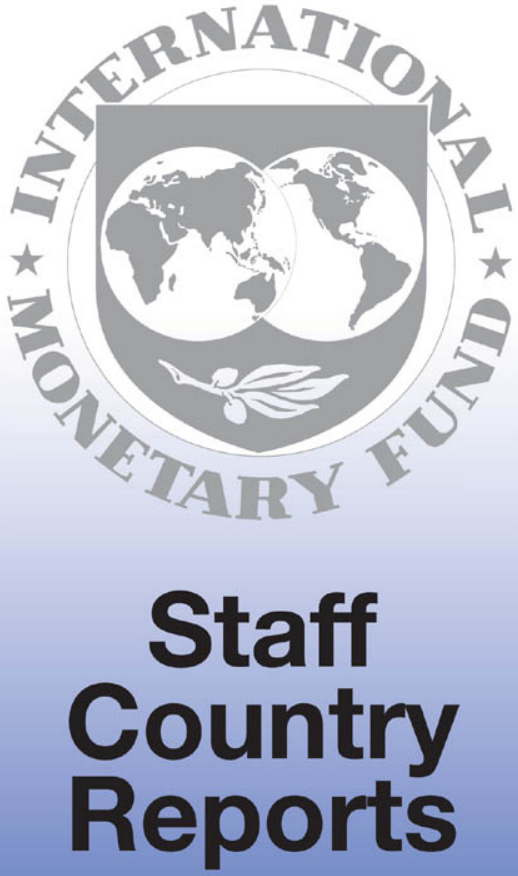


\section{United Kingdom: Selected Issues Paper}

This paper was prepared based on the information available at the time it was completed on July 13, 2011. The views expressed in this document are those of the staff team and do not necessarily reflect the views of the government of the United Kingdom or the Executive Board of the IMF.

The policy of publication of staff reports and other documents by the IMF allows for the deletion of market-sensitive information.

Copies of this report are available to the public from

International Monetary Fund • Publication Services

700 19th Street, N.W. • Washington, D.C. 20431

Telephone: (202) 623-7430 • Telefax: (202) 623-7201

E-mail: publications@imf.org • Internet: http://www.imf.org

\section{International Monetary Fund \\ Washington, D.C.}




\section{INTERNATIONAL MONETARY FUND}

\section{UNITED KINGDOM}

\section{Selected Issues}

Prepared by Kevin Fletcher, Prakash Kannan, Marta Ruiz-Arranz, and Hajime Takizawa (all EUR)

Approved by the European Department

July 13, 2011

Contents

I. A Bumpy Road Ahead-The Near-Term Outlook for Inflation in the UK $\underline{3}$

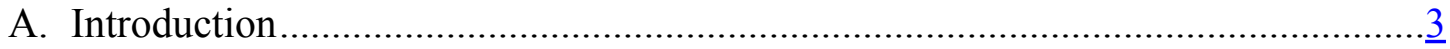

B. A Decomposition of Recent Inflation Developments ........................................

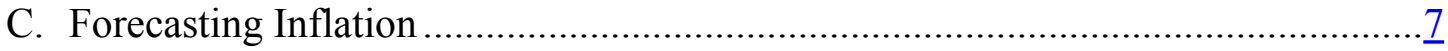

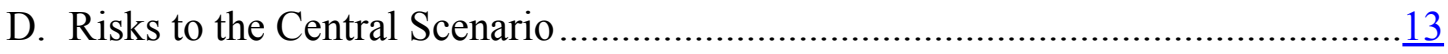

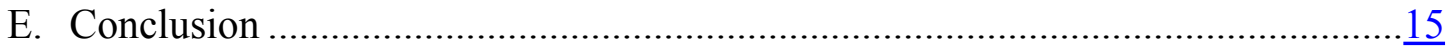

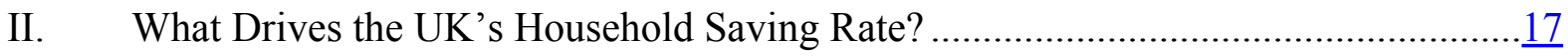

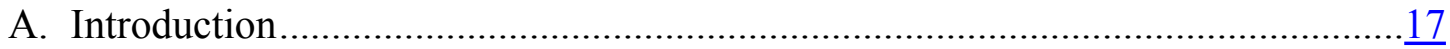

B. Potential Factors Driving the Household Saving Rate ……………………….... 18

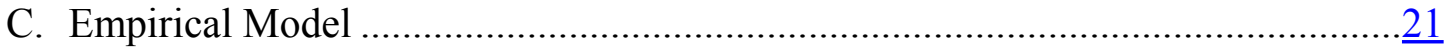

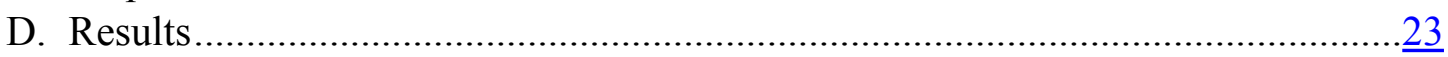

E. Using the Model to Project the UK Household Saving Rate.................................26

F. Implications of the Projections for Household's Balance Sheets ……...................27

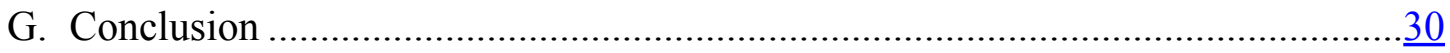

III. Vulnerabilities of Household and Corporate Balance Sheets and Risks for the

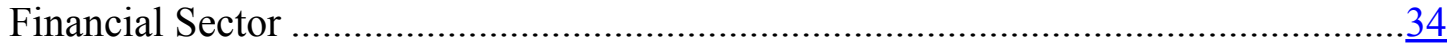

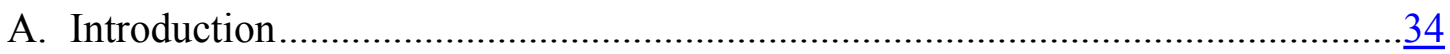

B. Household and Financial Sector Linkages.........................................................

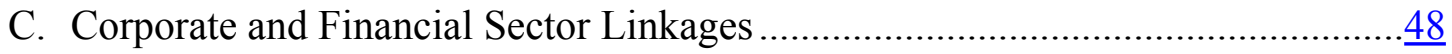

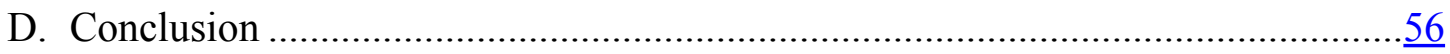

Figures

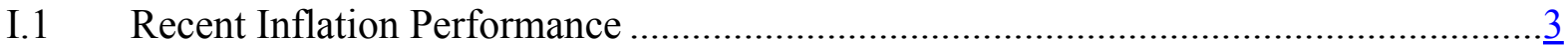

I.2 Decomposition of Recent Inflation Developments ................................................... 1 
I.3 Inflation Projections Using Various Models............................................................11

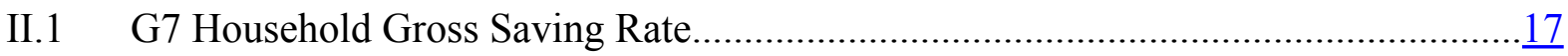

II.2 Saving Rate and Contribution to Its Changes .......................................................

II.3 Fitted Saving Rates for UK and G7 Average excl. UK and Contributions to Their

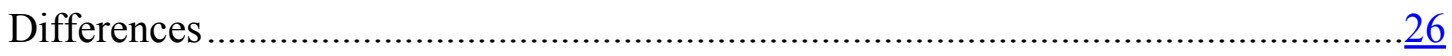

II.4 Comparison of Fitted Saving Rates-UK, UK Fitted for Other G7 Variables, and

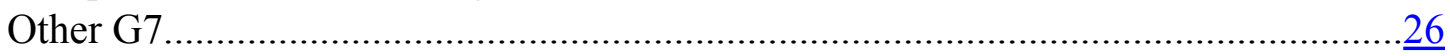

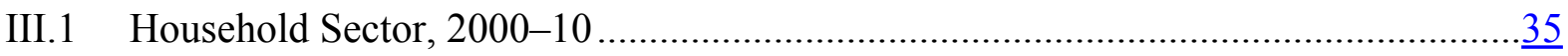

III.2 Household Balance Sheets and Mitigating Factors During the Crisis ..........................36

III.3 Household Sector Write-off Rates and Nonperforming Loans..................................

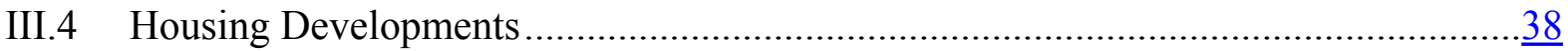

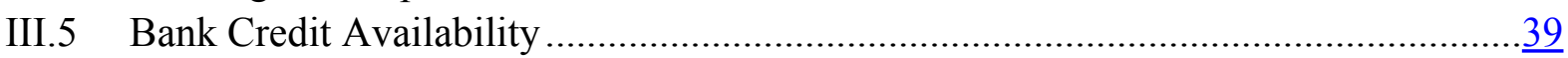

III.6 Household Debt Service-to-Income Ratio by Income Groups ................................... 42

III.7 Sensitivity Analysis of the Household Sector.........................................................

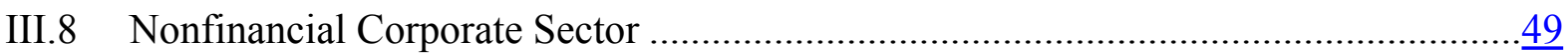

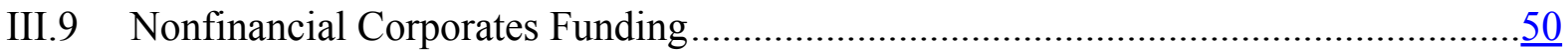

III.10 Debt at Risk of Nonfinancial Corporates.....................................................

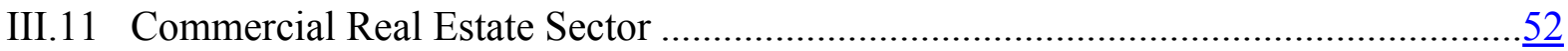

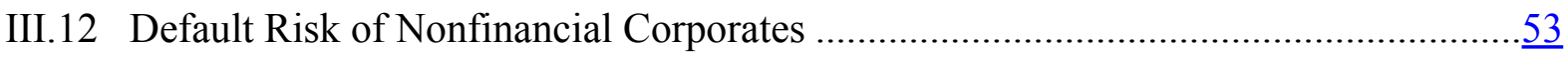

III.13 Contingent Claims Analysis of the Corporate Sector ............................................55

III.14 Sensitivity Analysis of the Nonfinancial Corporate Sector .......................................

Tables

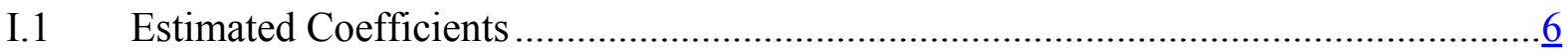

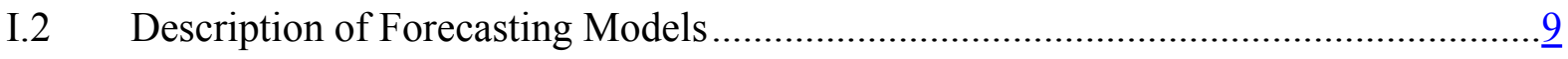

I.3 Relative Root Mean Squared Forecast Errors.....................................................

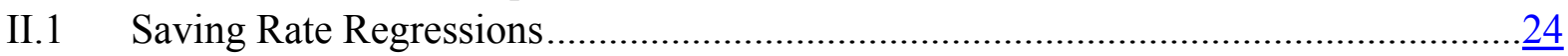

III.1 Descriptive Statistics by Income Category ........................................................... 41

III.2 Sensitivity Analysis of Household Sector: Baseline, September 2010........................ $\underline{45}$

III.3 Sensitivity Analysis of Household Sector: Summary of Shocks ................................. 48

Boxes

III.1 Contingent Claims Analysis ..........................................................................

Appendices

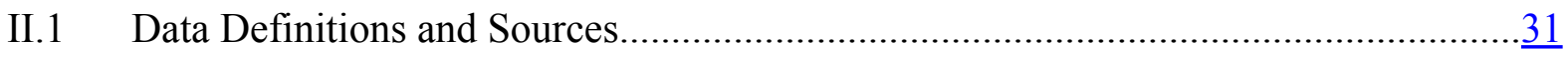




\section{A BUMPy ROAD AHEAD-THE NEAR-TERM OUTLOOK FOR INFLATION IN THE UK ${ }^{1}$}

\section{A. Introduction}

\section{Headline inflation in the UK is currently the highest amongst major advanced} economies. CPI inflation has exceeded the official target of 2 percent since December 2009. These overruns have been largely unanticipated by most forecasters due in part to unexpected increases in international commodity prices. Despite constant upward revisions to the Bank of England (BoE)'s forecasts, inflation has continued to surprise on the upside. The average one-year ahead forecast error was close to $1 \frac{3 / 4}{4}$ percentage points in 2010 . These overruns have heightened attention on the inflation outlook.

Figure 1. UK: Recent Inflation Performance
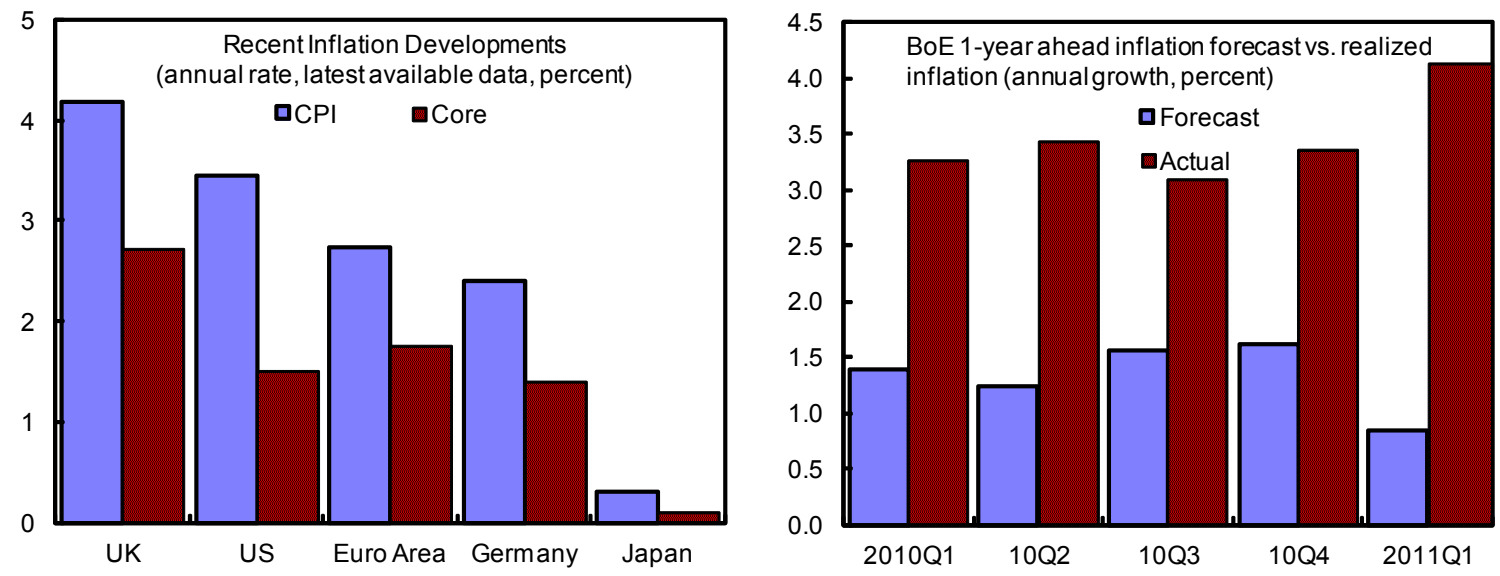

Sources: Haver, Bank of England, and IMF staff estimates.

2. Against this background, this chapter examines the main drivers of UK inflation, what they imply for the near-term inflation outlook, and risks surrounding this central scenario. The analysis in this chapter finds that transitory factors - spiking commodity prices and VAT rate hikes - have contributed substantially to recent inflation overruns. These same factors are expected to keep headline inflation well above 4 percent for most of 2011. As these transitory factors dissipate, inflation is expected to return close to the Bank of England's 2-percent target by end-2012 as downward pressure on inflation due to the negative output gap becomes more evident. Upside risks to this central scenario include a lack of resumption in productivity growth, higher commodity prices, and an output gap that is narrower than currently estimated.

3. The rest of this chapter is structured as follows: Section B first analyzes recent inflation developments. Section C then presents the details that underpin staff's near-term inflation forecast. Section D discusses key risks around this central scenario. Section E concludes.

\footnotetext{
${ }^{1}$ Prepared by Prakash Kannan (EUR).
} 


\section{B. A Decomposition of Recent Inflation Developments}

\section{To quantify the effects of several key drivers of recent inflation, an inflation} equation is estimated. The specification is motivated by the open-economy New Keynesian Philips Curve, which has been applied to the UK in various forms by Batini, Jackson, and Nickell (2005) and Dwyer, Lam, and Gurney (2010). A statistical significance criterion is used to determine a parsimonious lag structure. The specification, along with the description of the variables used, is as follows:

$$
\pi_{t}=\alpha+\beta_{1} \pi_{t-2}+\beta_{2} \pi_{t-1}^{E}+\beta_{3} \text { gap }_{t-8}+\beta_{4} u w c_{t-2}+\beta_{5} \text { neer }_{t-1}+\beta_{6} \text { comm }_{t}+\beta_{7} \Delta V A T+\varepsilon_{t}
$$

where

$$
\begin{aligned}
& \pi \quad=\quad \text { monthly inflation rate, annualized }{ }^{2} \\
& \pi^{E} \quad=\quad \text { medium-term inflation expectations } \mathrm{s}^{3} \\
& \text { gap }=\text { output gap as a percent of potential GDP }{ }^{4} \\
& u w c=\text { percentage change in unit wage } \operatorname{cost}^{5} \\
& \text { neer }=\text { percentage change in the nominal effective exchange rate (annual rate, a } \\
& \text { positive number indicates an appreciation) } \\
& \text { comm }=\text { percentage change in global commodity price index (annual rate) }{ }^{6} \\
& V A T=\text { standard value-added tax rate }
\end{aligned}
$$

\section{Most of the variables in equation (1) are fairly standard in single-equation} models of inflation. Some less-standard variables are also included in equation (1) due to their potential importance in explaining recent movements in inflation. These variables include the following:

\footnotetext{
${ }^{2}$ Monthly inflation is computed as $1200 * \ln \left(C P I_{t} / C P I_{t-1}\right)$.

${ }^{3}$ Implied inflation expectations based on 5-year zero-coupon inflation-indexed gilts. Implied RPI inflation rates from these gilts are multiplied by the average ratio of CPI to RPI inflation during the previous year to obtain CPI expectations.

${ }^{4}$ Estimated using a multivariate filter; see United Kingdom-Selected Issues (IMF, 2010).

${ }^{5}$ Typically, measures of the cost of labor to produce one unit of output take into account wages, salaries, pension contributions, social security payments, and benefits in kind. In the UK, only wages and salaries are used, hence the use of the terminology "unit wage cost" instead of the more common "unit labor cost".
}

${ }^{6}$ Available from the IMF’s International Financial Statistics. 
- VAT rate changes. In December 2008 the standard VAT rate was cut by 2.5 percentage points. This rate cut was reversed in January 2010. The standard rate was hiked by a further 2.5 percentage points in January 2011. The estimated full impact of each of these changes - assuming firms fully pass-through the tax

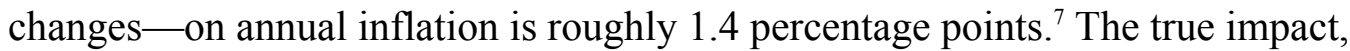
however, will be smaller if firms do not fully pass-through tax changes to final taxinclusive prices.

- $\quad$ Exchange rate. Sterling depreciated by 21 percent in nominal effective terms over the period 2008-2010. The effects of this large depreciation could potentially explain a non-trivial portion of recent inflation developments.

- Unit wage costs. The decline in employment during the recession was relatively mild compared to the fall in output. As a result, productivity - measured as output per worker-declined substantially. This decline in productivity, along with a rise in unemployment and lower inflation expectations, led to a decline in the average growth rate of wages. This decline, however, was not commensurate with the drop in productivity, resulting in higher unit wage costs. To offset the resulting pressure on profits, firms would likely have had to raise prices.

\section{Equation (1) is estimated using monthly data from January 1989 to}

December 2010. ${ }^{8}$ Table 1 shows the resulting estimated coefficients. All coefficients have the expected sign with regard to their theoretical impact on inflation and are statistically significant. ${ }^{9}$ Changes in the VAT rate have especially large effects on inflation. A 1 percentage point increase in the VAT rate results in a 0.4 percentage point increase in the annual inflation rate. The output gap is also found to have an important influence on inflation. A negative output gap of 1 percent reduces inflation by 0.2 percentage points about two quarters later. The coefficients in Table 1 estimate the short-run impact of changes in the explanatory variables. The cumulative effects are slightly larger given that inflation is autocorrelated.

\footnotetext{
${ }^{7}$ Bank of England, Inflation Report, February 2011.

${ }^{8}$ Monthly observations for data series that are only available at a quarterly frequency are based on interpolation.

${ }^{9}$ The statistical significance of the variables is partly by construction, as a significance criterion was used to determine the lag structure.
} 
7. The estimated coefficients are used to decompose recent inflation developments

(Figure 2). Exchange rate depreciation and higher unit wage costs contributed significantly to inflation in 2009, and somewhat moderately in 2010. The average impact of the exchange rate depreciation on annual inflation is estimated to be around 1.1 percentage points in 2009. By the third quarter of 2010, however, the impact had decreased to about 0.2 percentage points. The average contribution of unit wage costs during the period 2009-2010Q2 was 0.7 percentage points per quarter. Meanwhile, inflation expectationsand the internal dynamics of the inflation process - made a smaller-than-usual contribution to inflation during 2009. The subsequent rise in inflation expectations in 2010, however, has raised this contribution back to its pre-crisis average. The VAT rate hike of 2.5 percentage points in January 2010 increased headline inflation by about 1 percentage point. ${ }^{10}$ Meanwhile, commodity prices contributed about 0.5 percentage points to the headline inflation rate
Table 1. Estimated Coefficients 1

\begin{tabular}{|c|c|}
\hline Inflation (t-2) & $\begin{array}{c}0.157 \\
(0.053)\end{array}$ \\
\hline Medium-term expectations ( $\mathrm{t}-1)$ & $\begin{array}{c}0.438 \\
(0.107)\end{array}$ \\
\hline Output gap (t-7) & $\begin{array}{c}0.210 \\
(0.113)\end{array}$ \\
\hline Unit wage cost (t-2) & $\begin{array}{c}0.168 \\
(0.039)\end{array}$ \\
\hline Exchange rate $(\mathrm{t}-1)$ & $\begin{array}{l}-0.071 \\
(0.021)\end{array}$ \\
\hline Commodity prices & $\begin{array}{c}0.022 \\
(0.007)\end{array}$ \\
\hline VAT changes & $\begin{array}{c}4.847 \\
(0.535)\end{array}$ \\
\hline Constant & $\begin{array}{c}0.315 \\
(0.304)\end{array}$ \\
\hline N & 263 \\
\hline R-squared & 0.457 \\
\hline
\end{tabular}

Source: IMF staff estimates

\section{Excluding the impact of commodity prices and VAT tax hikes, underlying inflation is below 2 percent. The} decomposition of headline inflation based on the coefficients in the estimated model above implies that the underlying inflation rate- once the impact of commodity prices and tax hikes are removed - averaged around $1 \frac{1}{2}$ percent in the third and fourth quarters of 2010. Similar results are also obtained when the estimated impact of VAT hikes is subtracted from a measure of core inflation, which excludes energy, food, tobacco, and alcoholic beverages.

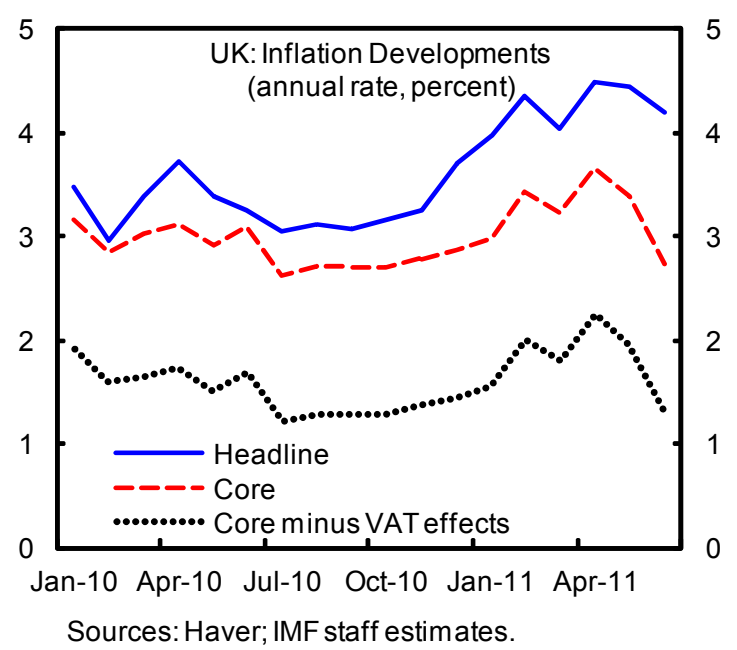
As this measure of core inflation excludes items that are largely not subject to VAT, the estimated impact of VAT hikes on its annual growth rate is roughly $1 \frac{1}{2}$ percentage points

\footnotetext{
${ }^{10}$ The cumulative effect after 1 year would be about 1.2 percent.
} 
(inclusive of long-term effects). This adjusted measure of core inflation is currently below $1 \frac{1}{2}$ percent, bringing it much closer to rates in other advanced economies.

Figure 2: Decomposition of Recent Inflation Developments (percentage points of annual rate)

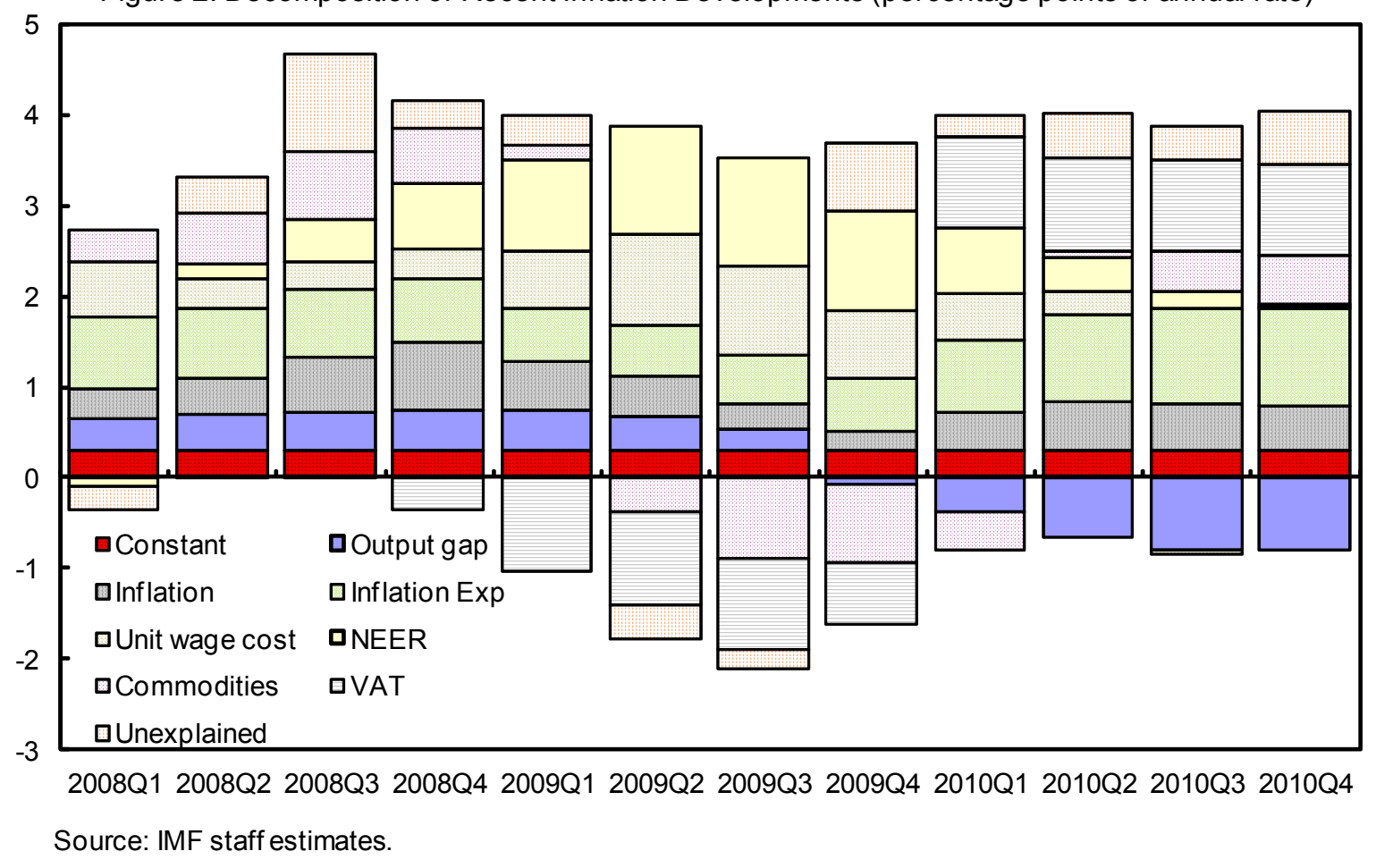

\section{Forecasting Inflation}

9. Even after accounting for the factors included in the inflation equation, there were large positive surprises to inflation over the last two years, particularly in 2010. The cumulative unexplained portion of annual inflation for the last three quarters of 2010 averaged around 0.5 percentage point per quarter. This large unexplained component has raised some concern regarding the near-term outlook for inflation, which this section addresses.

10. Two broad approaches are used to forecast inflation. The first approach embeds the inflation equation specified above within a vector auto-regression (VAR) model that generates endogenous forecasts for the dependent variables. The forecasting performance of this "restricted VAR" model is compared to a suite of other standard inflation forecasting models and is shown to perform well. The second approach employed to forecast inflation is based on separate forecasts for disaggregated components of the CPI, namely the core, energy, and food subcomponents. 


\section{Restricted VAR model}

\section{The central forecast for inflation in the UK builds on the single equation}

presented in the previous section. Specifically, equation (1) is embedded in a 5-variable VAR(8) model with changes in global commodity prices and the VAT rate included as exogenous variables. The coefficients in the inflation equation of the VAR are restricted such that lagged values of variables that are not included in equation (1) are set to zero. The coefficients in the inflation equation in the VAR, therefore, have roughly the same magnitudes as in the previous section, such that the equation is not over-parameterized. In addition to these restrictions, the impact of VAT changes on the other variables in the system (apart from inflation) is set to zero.

\section{Historical forecasting performance of inflation models}

\section{The usefulness of the restricted VAR model in forecasting inflation is tested} using its historical forecasting performance. To determine the model's relative forecasting performance, the forecasting performance of 10 different models (including the baseline restricted VAR model) - ranging from relatively naïve models, such as the unconditional mean and a random walk, to a model that incorporates dynamic factors-are compared. Table 2 describes the models.

\section{The three other VAR models included in the exercise represent robustness} checks to the baseline model. The VAR2 model is set up as a more conventional VAR model where no constraints are imposed on the inflation equation. The VAR3 and VAR4 models are analogous to the VAR1 and VAR2 models, but with trend output measured using a Hodrick-Prescott filter rather than the multivariate filter used in the baseline model.

\section{Inflation is forecast using monthly data over four forecast horizons $-\mathbf{3}$ months, 6} months, 12 months, and 24 months. Over each of these forecasting horizons, average inflation rates are forecasted rather than point estimates at individual horizons. Specifically, the inflation forecast over horizon $h$ is computed as

$$
\hat{\pi}_{t+h}=\frac{1}{h} \sum_{s=1}^{h} \pi_{t+s}^{f}
$$

where $\pi_{t+s}^{f}$ is the monthly inflation rate forecast. ${ }^{11}$ The inflation forecasting performance of these models over longer horizons are therefore judged based on whether or not they can adequately predict average inflation over that horizon. This approach is similar to that used in Stock and Watson $(1999,2002)$, with the exception that inflation is modeled as an I(0) process rather than an $\mathrm{I}(1)$.

\footnotetext{
${ }^{11}$ Given the definition of monthly inflation in footnote 1, the inflation forecast over a horizon $h$ can equivalently be stated as

$$
\hat{\pi}_{t+h}=\frac{1200}{h} \ln \left(C P I_{t+h} / C P I_{t}\right)
$$
}


Table 2. Description of Forecasting Models

\begin{tabular}{|c|c|}
\hline Model Name & Description \\
\hline $\mathrm{AR}$ & $\begin{array}{l}\text { Auto-regressive model with varying lag-length selection based on the } \\
\text { Bayesian Information Criterion. }\end{array}$ \\
\hline RW & $\begin{array}{l}\text { Random walk model. Forecasts at all horizons are set equal to the last } \\
\text { observation. }\end{array}$ \\
\hline UM & $\begin{array}{l}\text { Forecasts are based solely on the unconditional mean, which is computed } \\
\text { on a rolling basis using data up to the point of the start of the forecasting } \\
\text { period }\end{array}$ \\
\hline PC1 & $\begin{array}{l}\text { A Phillips Curve model that uses lagged values of inflation, the output gap, } \\
\text { and import prices. }\end{array}$ \\
\hline PC2 & Similar to PC1, but with unemployment instead of the output gap. \\
\hline DF & $\begin{array}{l}\text { A dynamic factor model estimated as a VAR with inflation and the first } \\
\text { principal component of a large set of economic indicators. }{ }^{12}\end{array}$ \\
\hline VAR1 & Baseline restricted VAR model, as described in text. \\
\hline VAR2 & $\begin{array}{l}\text { Endogenous variables are the same as in VAR1 with the exception that no } \\
\text { constraints are imposed on the inflation equation nor on the impact of VAT } \\
\text { on the other variables. }\end{array}$ \\
\hline VAR3 & $\begin{array}{l}\text { Endogenous variables are the same as in VAR1 (including the } \\
\text { restrictions), but a Hodrick-Prescott filter is used to determine the output } \\
\text { gap. }\end{array}$ \\
\hline VAR4 & $\begin{array}{l}\text { Same setup as in VAR3, but without any restrictions on the inflation } \\
\text { equation. }\end{array}$ \\
\hline
\end{tabular}

Source: IMF staff analysis.

\section{The models are estimated on monthly data that range from January 1988 to}

September 2010. The out-of-sample forecasts are based on a rolling estimation with the first estimation window covering January 1989 to December 1999 (1988 values are used as presample values). The last 24-month forecast, therefore, is based on an estimation from January 1989 to September 2008. This approach yields 108 individual forecasts for each model which are subsequently compared to actual inflation outturns.

16. The forecasting performance of these models is assessed based on the squared distance between the forecasted and realized values. Specifically, the root mean-squared error (RMSE) criterion is applied where

\footnotetext{
${ }^{12}$ The set of indicators comprise more than 50 data series covering a broad range of categories that include indicators of activity, trade, financial conditions, the labor market, housing conditions, and income.
} 


$$
R M S E_{h}=\sqrt{\frac{1}{T} \sum_{t=1}^{T}\left(\pi_{t+h}-\hat{\pi}_{t+h}\right)^{2}} .
$$

with $\pi_{t+h}$ being the actual average monthly inflation rate between period $t$ and $t+h$.

17. Table 3 lists the relative forecasting performance of the various models. The RMSE of each model is shown relative to the RMSE of the AR model, which serves as a benchmark. ${ }^{13}$ In general, the VAR models perform fairly well relative to the AR benchmark. The baseline restricted VAR model (VAR1) does particularly well with a one-year-ahead forecasting performance that is about 15 percent better than the AR model. The unrestricted version of the baseline model (VAR2) performs just as well, with slightly better forecasting performance over the longer horizons.

Table 3. Relative Root Mean Squared Forecast Errors

\begin{tabular}{lcccc}
\hline \multirow{2}{*}{ Model Name } & \multicolumn{5}{c}{ Forecast Horizon } \\
\cline { 2 - 5 } AR & 3 months & 6 months & 12 months & 24 months \\
RW & 1.00 & 1.00 & 1.00 & 1.00 \\
UM & 1.38 & 1.62 & 1.89 & 2.26 \\
PC1 & 1.10 & 1.10 & 1.10 & 1.22 \\
PC2 & 1.12 & 1.17 & 1.38 & 1.09 \\
DF & 1.06 & 1.11 & 1.33 & 1.47 \\
VAR1 & 1.00 & 0.98 & 0.98 & 1.05 \\
VAR2 & 0.95 & 0.89 & 0.95 & 1.05 \\
VAR3 & 0.99 & 0.82 & 0.75 & 0.98 \\
VAR4 & 0.99 & 0.97 & 1.05 & 1.38 \\
Memo: & 1.01 & 0.91 & 0.91 & 1.17 \\
RMSE of AR Model & 1.68 & 1.39 & 1.16 & 0.90 \\
\hline Soure: IMF saffCal & & & &
\end{tabular}

Source: IMF staff calculations.

${ }^{13}$ As shown in Kapetonis et al. (2007), the AR model typically yields the best forecasts. 


\section{Central inflation forecast}

18. Based on their relatively strong forecasting record, VAR models $\mathbf{1}$ and $\mathbf{2}$ are estimated using the most recent available data to obtain forecasts for the next two years. In order to do so, however, projections for the exogenous variables-global commodity prices and VAT changes - are required. In the case of oil prices, futures prices are used as the expected oil price in the central scenario. Based on the average futures price for Dubai, Brent, and West Texas Intermediate, the average petroleum spot price is expected to stay broadly flat over the next two years. For global food prices, however, data for equivalent contracts are not readily available. Instead, global food prices are assumed to increase by 0.4 percent per month - similar to the rate of increase during 2000-2006 (a relatively "normal" period). Meanwhile, future VAT changes are assumed to be zero.

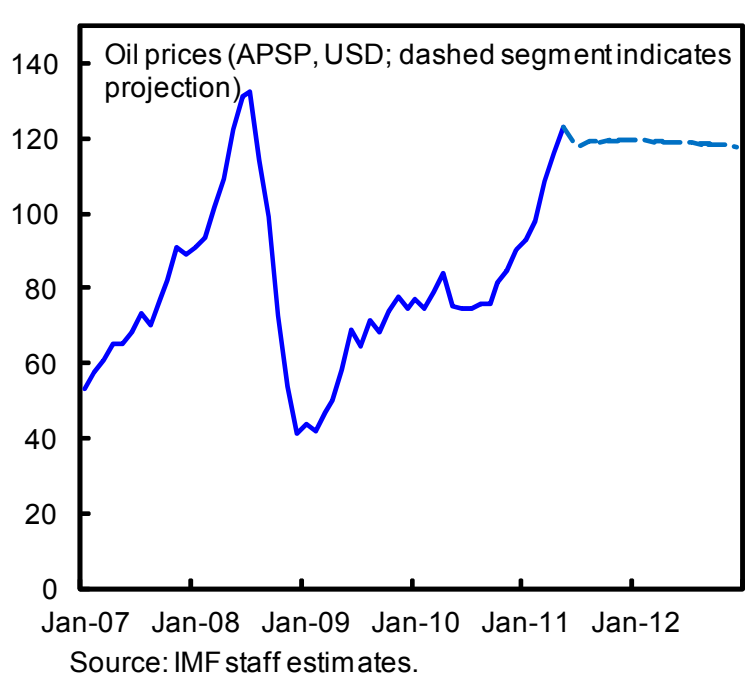

19. Inflation projections based on the two VAR models point to a hump-shaped forecast, with inflation exceeding 4 percent for most of 2011 (Figure 3). As the base effect of the VAT increase wears off, inflation moderates close to the 2 percent target by end-2012. Forecasts based on some of the other better-performing models point to a similar humpshaped forecast. The inflation path based on the DF model, for example, has a fairly similar path to the average of the two VAR models.

Figure 3. Inflation Projections using Various Models (percent, annual rate)

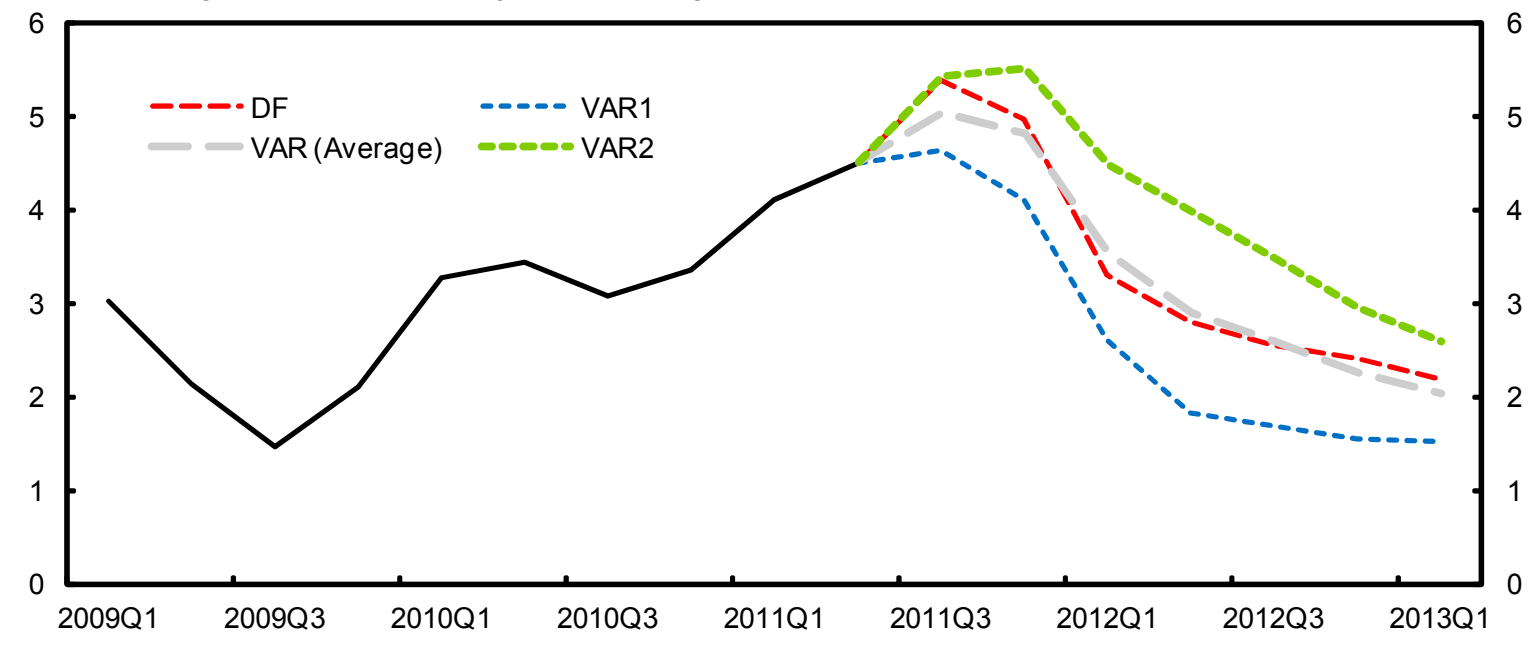

Sources: IMF staff estimates. 


\section{A “disaggregated" approach to forecasting inflation}

20. The second approach to forecasting inflation is based on a disaggregated approach that forecasts three broad subcomponents of the CPI-core, food, and energy prices. ${ }^{14}$ The forecasts for core, energy, and food inflation are done in a relatively straightforward way. For core inflation, an AR(3) model based on monthly inflation - with the inclusion of changes in VAT - is used. ${ }^{15}$ Monthly changes in the energy and food subindices, on the other hand, are assumed to respond to global oil and food prices in the same way as they have in recent history. ${ }^{16}$ The future paths of global oil and food prices are assumed to be the same as in the previous section.

\section{Forecasts for the individual subcomponents are then aggregated to produce a} forecast for headline inflation. To account for second-round effects, half of the contribution of the energy and food sub-indices experienced in any given three-month period is assumed to affect core inflation in the following three months.

\section{The forecast for inflation based on this approach results in a forecast that is} similar to the restricted VAR model, albeit with slightly lower inflation rates in 2011 and a more rapid disinflation in 2012. Food and energy price inflation are expected to peak in the second and fourth quarters of 2011, respectively, and then gradually decline. Following the lapse of the base effects due to the VAT increase, core inflation is expected to fall to 1.6 percent.

\footnotetext{
${ }^{14}$ The measure of core used here excludes energy, food, alcoholic beverages, and tobacco. The prices of tobacco and alcoholic beverages are assumed to follow the same inflationary pattern as for food.

${ }^{15}$ The lag-length was selected based on the Bayesian Information Criterion. The relatively short time series of core inflation precludes a more elaborate specification.

${ }^{16}$ Specifically, the following two equations are estimated:
}

$$
\begin{aligned}
& \Delta \text { Energy }_{t}=3.64+0.15^{*} \Delta \text { Energy }_{t-1}+.06^{*} \Delta \text { oil }_{t}+.07^{*} \Delta \text { oil }_{t-1} \\
& \Delta \text { Food }_{t}=2.56+0.15^{*} \Delta^{a} \text { Global Food }_{t}
\end{aligned}
$$



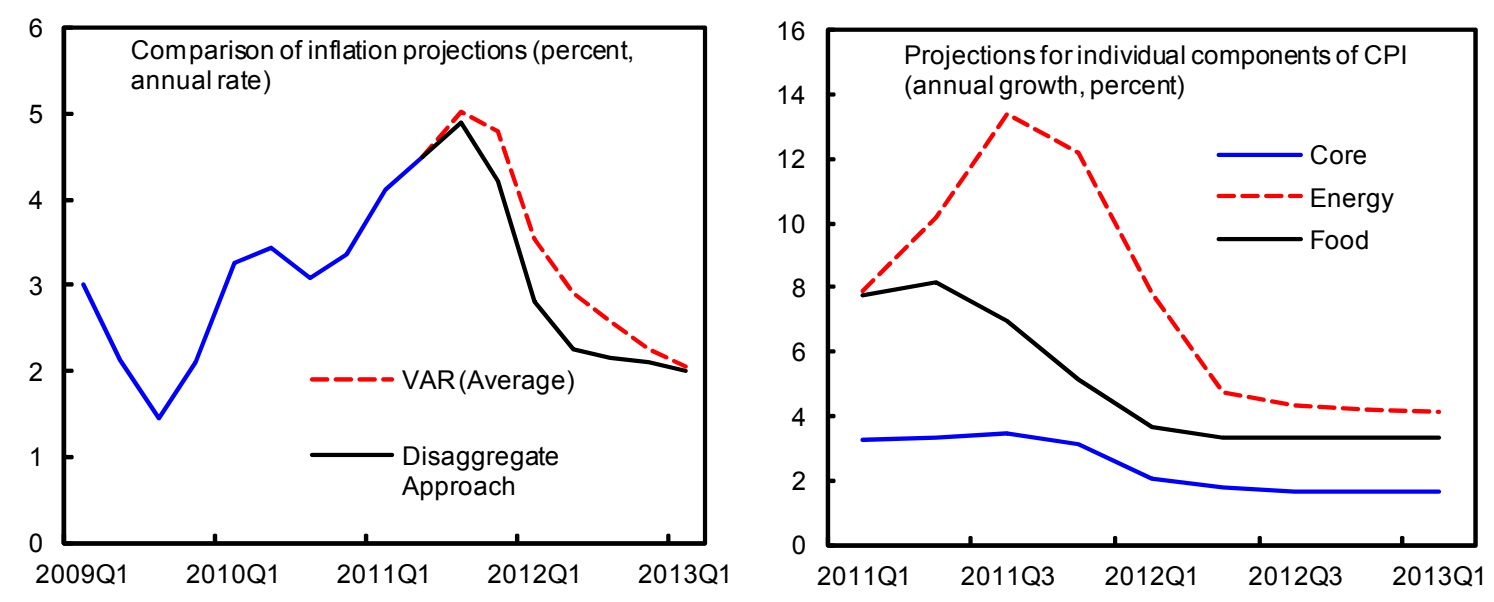

Sources: IMF staff estimates.

\section{Comparison of forecasts}

\section{The resulting inflation forecasts} are comparable to forecasts by other institutions, as well as market consensus. Forecasts for inflation during 2011 by the $\mathrm{BoE}$, the independent Office for Budget Responsibility (OBR), the OECD, and market consensus are all above 4 percent. Apart from the OECD (which has the lowest inflation forecast in 2012), forecasts for average inflation in 2012 by all these institutions continue to remain above the 2 percent target, though most forecasters expect inflation to return very close to the 2 percent target by end- 2012 .

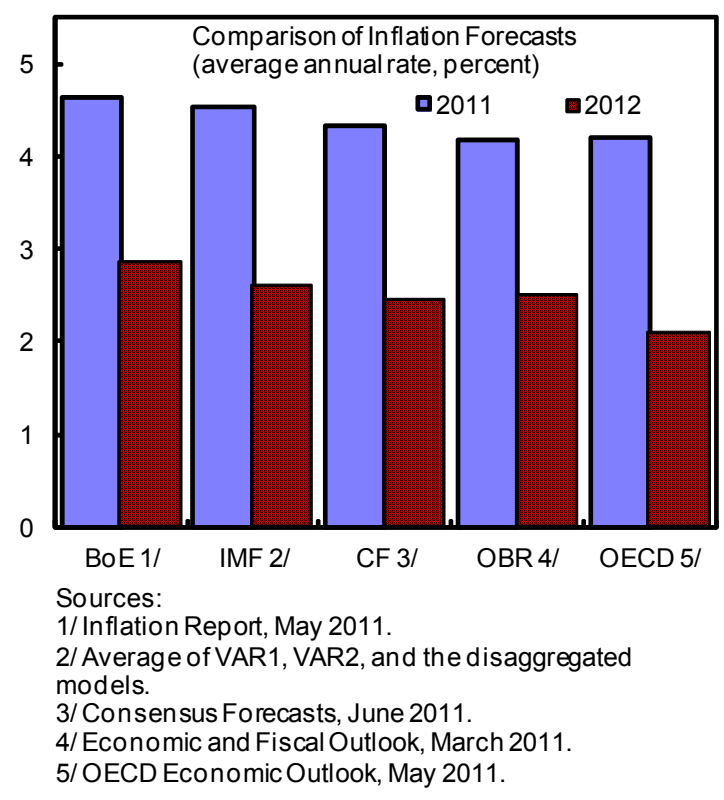

\section{Risks to the Central Scenario}

24. The forecasts above paint a relatively benign picture for inflation. After a bumpy period in 2011, inflation is expected to return close to the 2 percent target level by end-2012. In this section, we consider the risks around the central scenario. Three specific risks are considered: a rise in unit wage cost, a smaller output gap than is currently estimated, and higher commodity prices.

\section{Unit wage costs}

25. The central forecast for inflation is implicitly based on moderate growth in unit wage costs. From the third quarter of 2011, unit wage costs are expected to increase at an annual rate of 1 percent, which is lower than the pre-crisis average annual growth rate of 
2.2 percent. More subdued near-term growth in unit wage costs is plausible given the negative output gap and evidence of labor hoarding during the downturn, the unwinding of which should raise productivity.

\section{The implications of these projections for wage growth depend in part on the} outlook for productivity. Labor productivity - measured as output per worker - declined sharply during the past recession. Since then, growth in productivity has resumed at rates close to its historical average. If this fall in productivity is permanent, the implicit forecast of a 1 percent increase in unit wage costs implies wage growth of about 2.6 percent (assuming that productivity growth stays at its pre-crisis trend). Higher wage growth would lead to higher inflation than forecast in the central scenario. A more optimistic scenario is one where productivity growth is higher in the near-term such that its gap relative to trend is reduced. Under this scenario, the implicit forecast of a 1 percent growth in unit wage costs would be consistent with wage growth of over $3 \frac{1}{2}$ percent.

\section{There are both upside and downside risks to the central forecast for inflation} arising from wage developments. On the downside, there is a risk that unemployment rates remain high, or even increase, if the recovery in output turns out to be more sluggish than expected. In this scenario, wage growth will remain moderate with commensurate downward pressure on inflation. On the upside, increases in inflation expectations could give rise to higher wage growth, potentially leading to a wage-price inflation spiral. Recent measures of inflation expectations, however, remain well-anchored.

\section{Spare capacity measures}

28. A particularly important upside risk to the central inflation projection is that the output gap is not as large as is currently estimated. In the central forecast, the output gap is a significant deflationary factor in both 2011 and 2012. The output gap contributes a deflationary impact to annual inflation of about 0.5 and 0.4 percentage points in 2011 and 2012, respectively. While a variety of estimates-including by the OBR and the OECD - forecast output gaps to remain negative at end-2012, survey indicators of spare capacity suggest that the gap is narrowing at a faster rate. The upside risk to inflation of an output gap that is much smaller than currently estimated will be larger than just the direct impact stated above. A smaller degree of spare capacity will also place upward pressure on wages, all else remaining equal, thus contributing to further increases in inflation.

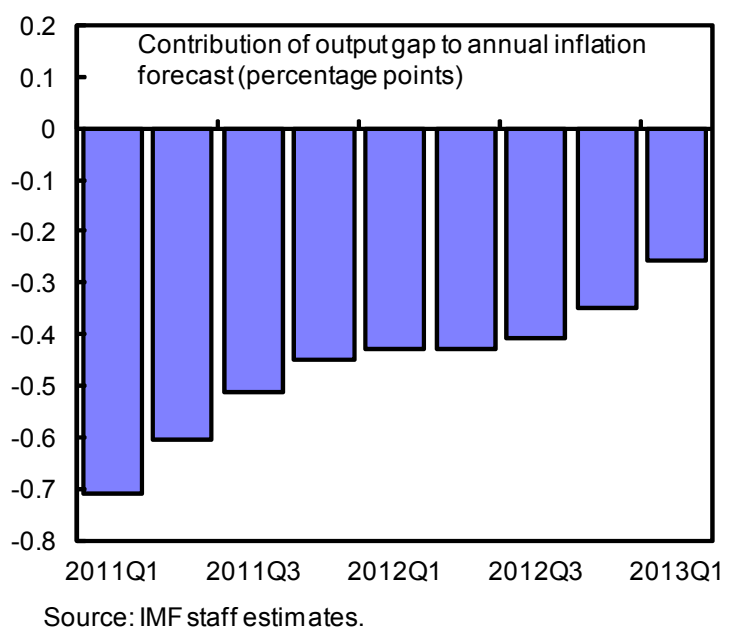




\section{Commodity prices}

29. Higher commodity prices pose a considerable upside risk to the central forecast. In the restricted VAR model, commodity prices contribute 0.6 percentage points to annual inflation in 2011. The importance of energy and food prices is individually taken into account in the disaggregated approach. Ignoring second round effects, a 10 percent increase in oil is estimated to increase headline inflation by 0.1 percentage points. The impact of an equivalent increase in global food prices, on the other hand, is estimated to be about 0.2 percentage points. While predictions based on futures contracts suggest a broadly stable outlook for oil prices, risks are tilted to the upside. ${ }^{17}$

\section{E. Conclusion}

30. Recent inflation overruns have largely been driven by temporary factors. Shocks to the price level arising from VAT and global commodity prices have kept inflation above target in recent months. Exchange rate depreciation and the impact of labor hoarding during the recession on unit wage costs were significant contributors to inflation during 2009-10.

\section{As temporary factors dissipate, inflation is expected to return close to the 2-} percent target by end-2012. The inflation model presented in this chapter-which takes the aforementioned factors into account — points to a moderation in the inflation rate in 2012 based on relatively stable commodity prices and an output gap that gradually narrows. The path to the target, however, is a bumpy one. Inflation is expected to remain well above 4 percent during 2011 before the base effect due to the VAT increase disappears and the disinflationary forces due to the negative output gap become more evident.

32. However, leading inflation indicators should be monitored closely. The evidence in this chapter suggests that movements in unit wage costs, inflation expectations, and other variables help predict future inflation. If the paths of these variables begin to deviate from the central scenario, inflation projections should be adjusted accordingly. If the shock to inflation is expected to be persistent, macroeconomic policy will also likely need to adjust.

\footnotetext{
${ }^{17}$ The implied probability distribution of oil prices for 2011 (estimated based on options prices) indicate a positive skew coefficient of 0.4 .
} 


\section{REFERENCES}

Batini, N., B. Jackson, and S. Nickell, (2005), “An Open-Economy New Keynesian Phillips Curve for the UK," Journal of Monetary Economics, Elsevier, vol. 52(6), pp. 1061-1071, September.

Dwyer, A., K. Lam, and A. Gurney, (2010), "Inflation and the Output Gap in the UK," Treasury Economic Working Paper No. 6.

Kapetanios, G, V. Labhard, and S. Price (2007), "Forecast Combination and the Bank of England's Suite of Statistical Forecasting Models," Working Paper No. 323, Bank of England.

Stock, J., and M. Watson, (1999), "Forecasting Inflation," Journal of Monetary Economics, Elsevier, vol. 44(2), pp. 293-335, October.

, (2002), "Macroeconomic Forecasting Using Diffusion Indexes," Journal of

Business \& Economic Statistics, American Statistical Association, vol. 20(2), pages 147-62, April. 


\section{What DRIVES The UK's Household SAVING RATE?}

\section{A. Introduction}

\section{There is significant uncertainty surrounding the future path of the UK's}

household saving rate. The UK's gross household saving rate has long been one of the lowest among G7 economies (Figure 1). ${ }^{2}$ Indeed, the saving rate fell to very low levels during the pre-crisis boom, reaching a nadir of 2 percent in 2008 (annual rate). It subsequently rose sharply to 6 percent in 2009 in the wake of the financial crisis. Although it began declining slightly again last year to 5.3 percent, it remains well above pre-crisis levels. This higher saving rate could reflect heightened uncertainty and households' efforts to strengthen their balance sheets following the bust of an unsustainable balance sheet expansion in the run-up to the financial crisis, among other factors. Historical episodes suggest that deleveraging following run-ups in household debt often takes many years, as households slowly rebuild their net wealth through higher savings (see, for example, McKinsey Global Institute, 2010). This, and the fact that the UK household saving rate remains low by international standards, suggests that the saving rate may remain elevated for some time or even rise further. On the other hand, the household saving rate is currently high by recent UK historical standards, suggesting that the saving rate may continue to revert gradually back to pre-crisis levels. These conflicting considerations create substantial uncertainty about the future path of the

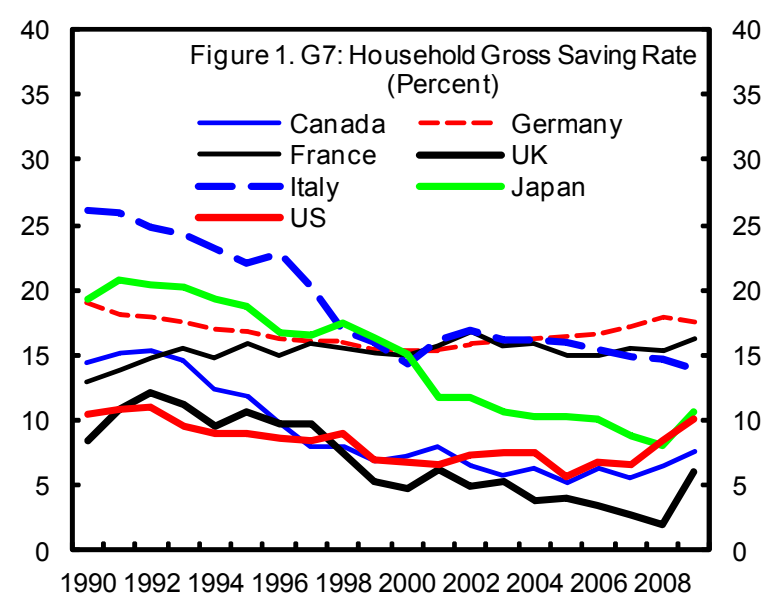

Sources: OECD; and IMF staff calculations. household saving rate.

\section{The outlook for the household saving rate is important to judging how the UK} economy will evolve over the medium term. Movements in the household saving rate have important effects on near-term growth, as private consumption accounts for two-thirds of GDP. The medium-term path of the household saving rate is also critical to determining the degree to which the economy will rebalance toward investment- and external-led demand.

\footnotetext{
${ }^{1}$ Prepared by Hajime Takizawa (EUR) with research assistance from Stephanie Denis (EUR).

${ }^{2}$ The gross household saving rate is defined as gross household saving divided by gross household gross disposable income. All references to the "household saving rate" in this chapter refer to the household gross saving rate, but the qualifier "gross" is dropped in most cases for brevity.
} 
3. Against this background, this chapter studies the determinants of the UK household saving rate using panel data for $\mathbf{G 7}$ economies. It finds that a substantial part of the UK's relatively low saving rate cannot be explained by standard variables and instead appears to reflect country-specific fixed effects. However, variations in the UK saving rate over time can be largely explained by several factors, including changes in housing wealth and the fiscal balance. These two factors appear to have been especially important drivers of changes in the saving rate during the last decade.

\section{The results suggest that the UK household saving rate is likely to stay broadly} flat in the medium term. On one hand, likely declines in the house price-to-income ratio will put upward pressure on the household saving rate. On the other hand, the ongoing implementation of a multi-year fiscal consolidation plan will put downward pressure on the saving rate, offsetting the effect emanating from house prices. However, the results are sensitive to assumptions regarding the future path of key explanatory variables.

\section{The rest of the chapter is organized as follows. Section B discusses potential} factors that could explain variation in the household saving rate and underlying economic theories. Section C discusses the empirical model. Section D discusses the empirical results and their interpretations. Section E uses the results and assumptions about the future path of explanatory variables to project the future path of the UK saving rate. Section F discusses the implications of this saving rate path for household balance sheets. Section G concludes.

\section{B. Potential Factors Driving the Household Saving Rate}

6. The analysis in this paper focuses on economic forces that are likely to influence the household saving rate. ${ }^{3}$ In particular, the following factors are studied:

- Demographic trends. The permanent income hypothesis implies that workers save part of their labor income while they are of working age to finance consumption in retirement. Once retired, they save less or even draw down on financial assets. In a similar vein, children usually do not have income, but still consume. A change in a country's demographic structure could therefore affect the aggregate household saving rate. In particular, the higher is the share of the population that is elderly or young, the lower the aggregate saving rate should be.

- Temporary income fluctuations. The permanent income hypothesis also implies that households should smooth consumption over the business cycle. From an economy-wide perspective, this effect implies that aggregate household savings should rise during cyclical booms and fall during cyclical downturns, all other things

\footnotetext{
${ }^{3}$ Hüfner and Koske (2010) offer a concise summary of determinants of the household saving rate explored in the literature.
} 
equal. Such cyclical economy-wide fluctuations in income could be proxied by variables such as the unemployment rate or estimated output gap.

- Real interest rate. The real interest rate is a potentially important determinant of the household saving rate. Changes in the real interest rate have both a substitution and an income effect. The substitution effect arises because a higher rate raises the opportunity cost of consumption today and should encourage saving. The income effect arises because higher real interest rates also increase the total amount of future consumption possible for any fixed amount of initial wealth. This income effect is likely to increase consumption today (and all future periods) and thus tends to create a negative relationship between real interest rates and saving. Whether the net effect of interest rates on saving is positive or negative depends on whether the substitution or income effect dominates. In addition to these effects, higher real interest rates might also redistribute income to individuals with higher propensities to save, thereby raising the saving rate.

- $\quad$ Fiscal balance. Government saving can influence household saving because government saving eventually affects household disposable income through taxes and transfers. Pure "Ricardian equivalence" is unlikely to hold in reality because its underlying assumptions (e.g., perfect capital markets) do not fully hold. However, existing research finds that government saving does affect household saving to some extent. This could reflect imperfect Ricardian effects or simply reflect sticky household consumption in the face of changes in taxes/transfers and associated changes in disposable income.

- Uncertainty. Uncertainty about future income streams might be one reason why riskaverse households save part of their income as a precaution against future income declines and associated consumption drops (Carroll, 2001). Past studies attempt to capture such uncertainties using variables that measure macroeconomic volatility, such as the inflation rate, the volatility of real GDP growth, or the unemployment rate.

- Wealth (net financial wealth). Together with income flows, net financial wealth represents part of household resources that can finance consumption. An increase in wealth is therefore likely to increase consumption today and lower the household saving rate, all other things equal. Confidence effects are another channel through which changes in net financial wealth resulting from asset price changes might affect saving behavior. ${ }^{4}$ The wealth effect has been studied extensively in the literature,

\footnotetext{
${ }^{4}$ Wealth variables — both financial and tangible (housing) - might also partly capture credit condition effects, as rapid asset price growth is likely to lead to loose credit conditions, and vice versa. Ideally, regressions would control for credit conditions directly, but comparable cross-country data on credit conditions are difficult to obtain.
} 
usually in the context of its relation to consumption growth (Ludwig and Sløk, 2002; Byrne and Davis, 2003), but also in analysis of the household saving rate (IMF, 2010).

- Wealth (tangible wealth). Tangible wealth, a large part of which is housing wealth, represents the remaining part of household wealth. However, housing wealth plays a role somewhat different from the one played by net financial wealth. Unlike net financial wealth, housing wealth generates a stream of housing services that owneroccupants consume. Appreciation of house prices, if matched by a commensurate increase in rents of comparable properties, can be thought of as an increase in the prices of current, as well as future, housing services that owner-occupied housing generates. As a result, higher housing wealth might not increase the present value of real resources available for non-housing consumption and therefore might not affect household saving, at least in theory. However, there are at least three reasons why higher housing wealth might increase consumption:

$>$ Liquidity constraints. The housing equity that grows with such house price appreciation can be withdrawn, either by selling the house or using equity loans. This may allow households to achieve higher consumption today (at the expense of less future consumption) that they desired before the house price appreciation but were unable to achieve due to liquidity constraints.

> Shift to non-housing consumption. Higher housing costs due to higher house prices could incentivize households to shift consumption toward lower-priced non-housing goods and services today and away from higher-priced future housing services. One example of this behavior is an elderly household taking a home equity loan to finance higher consumption today in the face of high house prices and in anticipation of downsizing of their housing earlier than previously planned. Such behavior would reduce the household saving rate.

$>$ Wealth illusion. Households might perceive the increase in their home equity more clearly than they perceive the associated increase in the implicit rental cost of owner-occupied housing, especially if rents on non-owner occupied housing do not rise commensurately (a common feature of housing bubbles). Such "wealth illusion" could prompt higher current consumption and lower saving rates. Similarly, permanent house price increases generate capital gains to homeowners cashing out of the housing market but make future first-time homebuyers worse off. Owners cashing out might perceive these capital gains more clearly than future first-time buyers perceive the higher future cost of owner-occupied housing.

Papers that study the effects of tangible wealth on the household saving rate at the macroeconomic level are somewhat limited, perhaps reflecting data availability. 


\section{Empirical Model}

7. The starting point of the empirical analysis is the following linear model of the saving rate:

$$
S A V_{i, t}=\alpha_{i}+\gamma_{i} \cdot \mathrm{t}+\beta \cdot \mathrm{x}_{\mathrm{i}, \mathrm{t}}+\varepsilon_{\mathrm{i}, \mathrm{t}}
$$

where $S A V_{i, t}$ is gross saving by households and nonprofit institutions serving households divided by gross disposable income. $\alpha_{i}$ captures country-specific, time-invariant effects; $\gamma_{i}$ represents the country-specific effect of the time trend; $\beta$ is a vector of coefficients of explanatory variables $\mathrm{x}_{\mathrm{i}, \mathrm{t}}$; and $\varepsilon_{\mathrm{i}, \mathrm{t}}$ is an error term. For parsimony, the coefficients $(\beta)$ for explanatory variables are restricted to be the same across countries-with a few exceptions discussed in the next paragraph — as the magnitude of most effects is expected to be broadly similar across countries.

\section{The choice of explanatory variables is guided by theories aimed at explaining} household saving behavior as well as some existing empirical findings in the literature. In particular, the following variables are used to capture the effects of economic forces underlying household saving behaviors discussed in the previous section and form a list of explanatory variables in the model:

- $\quad$ Dependency ratio (denoted by $\mathbf{D E P}$ ). This is defined as the share of the +65 population and 0-14 population in the total population. A higher dependency ratio should be associated with a lower saving rate because these "dependents" save less.

- $\quad$ Real long-term interest rate (denoted by $\boldsymbol{R} \boldsymbol{I R L}$ ). This is derived by subtracting the CPI inflation rate from the interest rate on the 10 -year government bond. The expected sign of the coefficient is negative, as the substitution effect is expected to dominate.

- $\quad$ General government fiscal balance (in percent of GDP; denoted by GGBY). Larger fiscal surpluses should be associated with lower household savings. The expected sign is negative.

- Inflation (log difference of CPI; denoted by INF). The expected sign of the coefficient is positive because inflation may capture macroeconomic uncertainty and because nominal interest income rises in times of high inflation-even if there is no real increase in income and therefore no real increase in consumption-causing measured household saving rates to rise (Jump, 1980).

- Unemployment rate (denoted by $\boldsymbol{U N R}$ ). This is an additional variable that potentially captures uncertainly associated with the probability of joblessness and income volatility. If this variable captures purely precautionary saving, the sign of the coefficient should be positive. However, households might use accumulated assets to 
smooth consumption in the face of income losses associated with joblessness, rather than increasing savings. If this effect dominates, the sign will be negative.

- $\quad$ Tangible wealth (in percent of gross disposable income; denoted by $\boldsymbol{H W}$ ). Some existing papers find that this effect is much stronger in economies with welldeveloped and highly flexible mortgage markets, which might increase effects related to liquidity constraints. Studies have observed that "Anglo-Saxon" economies exhibit such features most strongly. ${ }^{5}$ To take into account this observation, the specification is modified to let the variable $H W$ interact with a dummy variable for Anglo-Saxon economies (Canada, UK, and US) as follows:

$$
H W_{i, t}+D_{\text {Anglo-Saxon }} \cdot H W_{i, t}
$$

where $D_{\text {Anglo-Saxon }}$ is a dummy variable that takes a value of one for observations on Anglo-Saxon economies and zero otherwise. The coefficient of the first term is relevant for non-Anglo-Saxon economies while the sum of the first and the second terms represents the effect of $H W_{i, t}$ on the saving rate in Anglo-Saxon economies. The expected signs of the coefficients for both the first and second terms are negative.

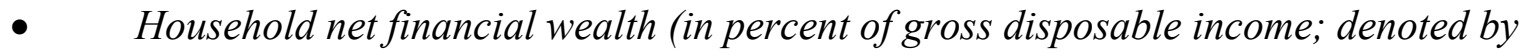
$\boldsymbol{N F \boldsymbol { H }}$ ). The expected sign is negative. As alternative variables, household gross financial assets $(\boldsymbol{F} \boldsymbol{A H})$ and liabilities $(\boldsymbol{F} \boldsymbol{L} \boldsymbol{H})$ can be used. Expected coefficients of these variables are negative and positive, respectively.

9. The analysis uses panel data for $\mathbf{G 7}$ economies. This choice of countries is driven by data availability, especially for households' tangible wealth. ${ }^{6}$ To ensure a balanced panel, the analysis uses data starting in $1980 .^{7}$

\section{For the UK, CPI excluding effects of indirect taxes is used instead of headline}

CPI ${ }^{8}$ CPI inflation in the UK has recently been heavily affected by changes in indirect taxes (especially the VAT rate). However, these tax changes are unlikely to affect significantly the economic uncertainty or changes in nominal interest income that the inflation variable is

\footnotetext{
${ }^{5}$ For example, see Slacalek (2009).

${ }^{6}$ The OECD does offer data on the index of the value of the housing stock as a percent of gross disposable income for a wider set of countries. However, because the data are index values, they cannot explain crosscountry differences in the saving rate level.

${ }^{7}$ Data for Germany and Japan start in 1980. Pre-unification (pre-1991) data for Germany are derived by splicing data on West Germany backward using growth rates.

${ }^{8}$ This official inflation measure is calculated by the UK Office for National Statistics by mechanically removing indirect taxes from prices, assuming full pass-through.
} 
trying to capture. It is therefore desirable to take out the effect of the VAT changes from CPI inflation, given that estimates for the UK are the central focus of the study.

\section{Results}

11. Data are stationary once adjusted for fixed and time effects. Some unadjusted explanatory variables appear non-stationary. However, when deviations of the time-series data from fitted values resulting from regressions of the explanatory variables on country fixed effects and time trends (as implied by the econometric specification above) are used, panel unit root tests based on individual ADF tests, a la Maddala and Wu (1999) and Choi (2001), reject the null hypothesis of a unit root at the 1 percent level for all series except the dependency ratio (DEP). However, this finding does not necessarily imply a unit root and may instead reflect insufficient test power.

\section{The estimated coefficients are reported in Table 1 and largely confirm the}

predictions discussed in the previous section. The baseline case uses household net financial wealth in the regression (column A). The coefficients of the long-term real interest rate and CPI inflation are both positive (one percentage point increases in the long-term real interest rate and CPI inflation result in 0.31 percentage point and 0.50 percentage point increases in the saving rate, respectively). The coefficients of the dependency ratio and the general government overall fiscal balance are negative (a one percentage point increase in the dependency ratio and a one percent of GDP increase in the balance result in 0.66 percentage point and 0.42 percentage point declines in the saving rate, respectively). The coefficient of the tangible wealth-to-gross disposable income ratio is positive for non-Anglo-Saxon economies. This implies that, contrary to predictions, higher tangible wealth raises saving in these countries. However, the magnitude of the coefficient is small, and it is only significant at the 10 percent level. In contrast, for Anglo-Saxon economies, the sign of the sum of the coefficient and the dummy term is sizeable, statistically significant at the 1 percent level, and - as predicted - negative (a one percentage point increase in the tangible wealth-toincome ratio results in a 0.03 percentage point decline in the saving rate). This is consistent with findings in the literature: the negative effect of housing wealth on the saving rate is evident in economies that are characterized by well-developed mortgage markets. The coefficient of the unemployment rate is statistically significant and has a negative sign, which suggests that this variable mainly captures the consumption-smoothing effect. 
Table 1. Saving Rate Regressions 1/ 2/ 3/

Dependent variable: Gross saving rate (SAV)

(A)

(B)

(C)

\section{Dependency ratio (DEP)}

Real long-term interest rate (RIRL)

General government overall balance (GGBY)

CPI inflation (INF)

Unemployment rate (UNR)

Household net financial wealth (NFWH)

Tangible wealth (HW)

Tangible wealth (HW), Anglo-Saxon

Lagged ( $t-1$ ) household net financial wealth (NFWH)

Lagged (t-1) tangible wealth (HW)

Lagged (t-1) tangible wealth (HW), Anglo-Saxon

Household gross financial assets (FAH)

Household gross financial liabilities (FLH)

Lagged (t-1) household gross financial assets (FAH)

Lagged (t-1) household gross financial liabilities (FLH)
Observations

Sample period

R-squared

$\begin{array}{cc}-0.6568^{* * *} & -0.7218^{* * *} \\ (-5.53) & (-6.05) \\ 0.3106^{* * *} & 0.2729^{* * *} \\ (3.90) & (3.42) \\ -0.4179^{* * *} & -0.4405^{* * *} \\ (-8.83) & (-9.30) \\ 50.4878^{* * *} & 48.6650{ }^{* * *} \\ (6.26) & (6.10) \\ -0.1784^{* *} & -0.20977^{* *} \\ (-2.20) & (-2.59) \\ 0.0063 & \\ (1.50) & \\ 0.0047^{*} & 0.0082{ }^{* * *} \\ (1.65) & (2.65) \\ -0.0347^{* * *} & -0.0316{ }^{* * *} \\ (-7.63) & (-6.83)\end{array}$

$-0.5694^{* * *}$

$(-4.29)$

0.2596 ***

$-0.4468 * * *$

$49.3581^{* * *}$

$-0.1135$

Sources: IMF staff estimates, using data whose sources are discussed in Appendix I.

$1 /$ Coefficients of country specific-constants and country-specific time trends are not reported for simplicity.

2/ Figures in parentheses are t-statistic values for the null hypothesis that the coefficient statistically is not significantly different from zero.

$3 /{ }^{* * *} p<0.01,{ }^{* *} p<0.05,{ }^{*} p<0.1$ 


\section{The results do not find the expected wealth effect associated with financial wealth.}

- $\quad$ Estimated coefficients of net financial wealth are not statistically significant. This result holds even when a one-year lag of household net financial wealth is used in the regression (not reported in the table for simplicity) to reduce potential endogeneity.

- As another robustness check, regressions are re-estimated using household gross financial assets and liabilities as explanatory variables. When contemporaneous gross financial assets and financial liabilities are used (column B in Table 1), only the coefficient of gross financial liabilities is statistically significant, but with an unexpected negative sign (a higher gross financial liability-to-gross disposable income ratio results in a lower saving rate). This suggests a possibility of endogeneity (i.e., a high saving rate leads to a low level of gross debt as households use saving to reduce their debts). When one-year lags of gross financial assets and liabilities are used as a way to control for endogeneity, however, the coefficients are not statistically significant (column $\mathrm{C}$ in Table 1), suggesting that the statistically significant negative coefficient of contemporaneous gross financial liabilities is due to endogeneity.

\section{Estimation results suggest that}

\section{housing wealth has contributed to the} very low level of the household saving rate in the UK. Figure 2 uses the estimated coefficients in column A to quantify the contributions of explanatory variables to changes in the saving rate over the last 15 years. ${ }^{9}$ These results suggest that the decline in the saving rate in the late 1990 s owes to improvements in the fiscal balance and increases in the value of housing wealth. Housing wealth continued to exert downward pressures on the saving rate during much of the decade leading up to the recent financial crisis; to a lesser extent, lower real interest rates also played a role.

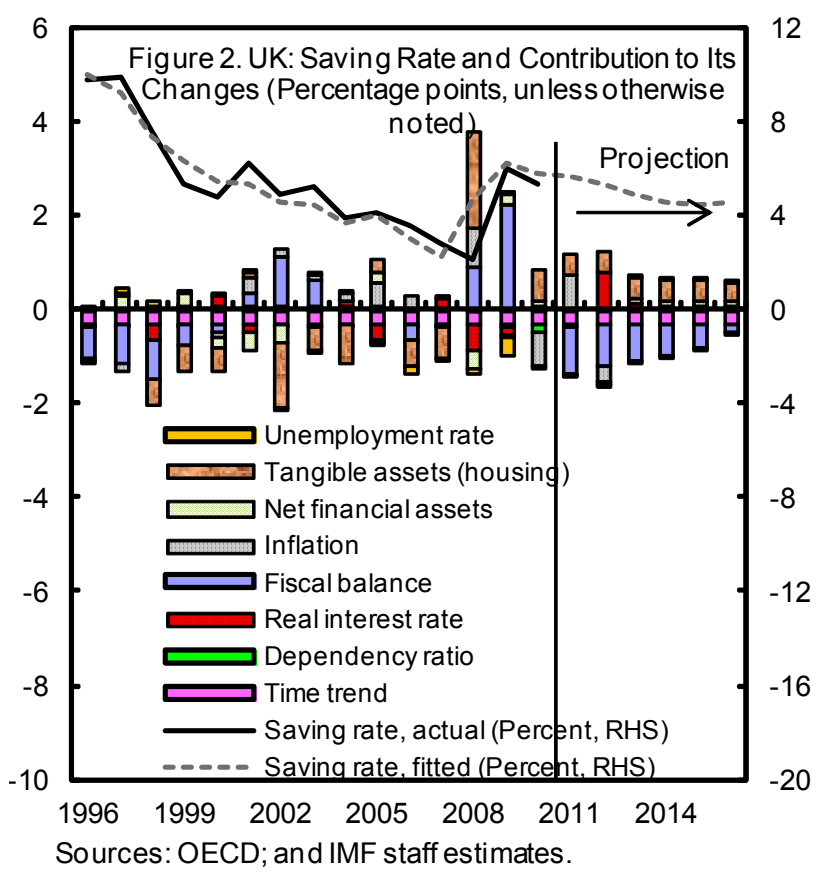

\footnotetext{
${ }^{9}$ The results from column A are used in all of the analysis behind the discussion in the rest of this chapter. However, the estimated effects do not change materially if other specifications are used, as the magnitude of the coefficients is broadly similar across the specifications.
} 


\section{Another way to look at the extent to which explanatory variables explain the} difference between the saving rate in the UK and other G7 countries is to compare fitted household saving rates. In particular, the average values of explanatory variables for the six G7 countries other than the UK can be used to derive fitted values that are then compared to the fitted value of the UK household saving rate (Figure 3). This exercise is equivalent to asking what the saving rate in the UK would have been had the explanatory variables been at the levels equal to the average of the six G7 countries other than the UK. Figure 3 shows that housing wealth is the single most important factor that has contributed to the growing difference in the household saving rate between the UK and other G7 countries. However, Figure 4 also shows that the low level of the household saving rate in the UK is not accounted for solely by differences in the explanatory variables. Indeed, the explanatory variables account for, on average, only about 35 percent of the difference between the UK saving rate and the average for other $\mathrm{G} 7$ countries over the last 10 years, with the remaining difference attributable to country fixed-effects and time trends. This indicates that other country-specific effects, such as institutions, are important in explaining the difference.
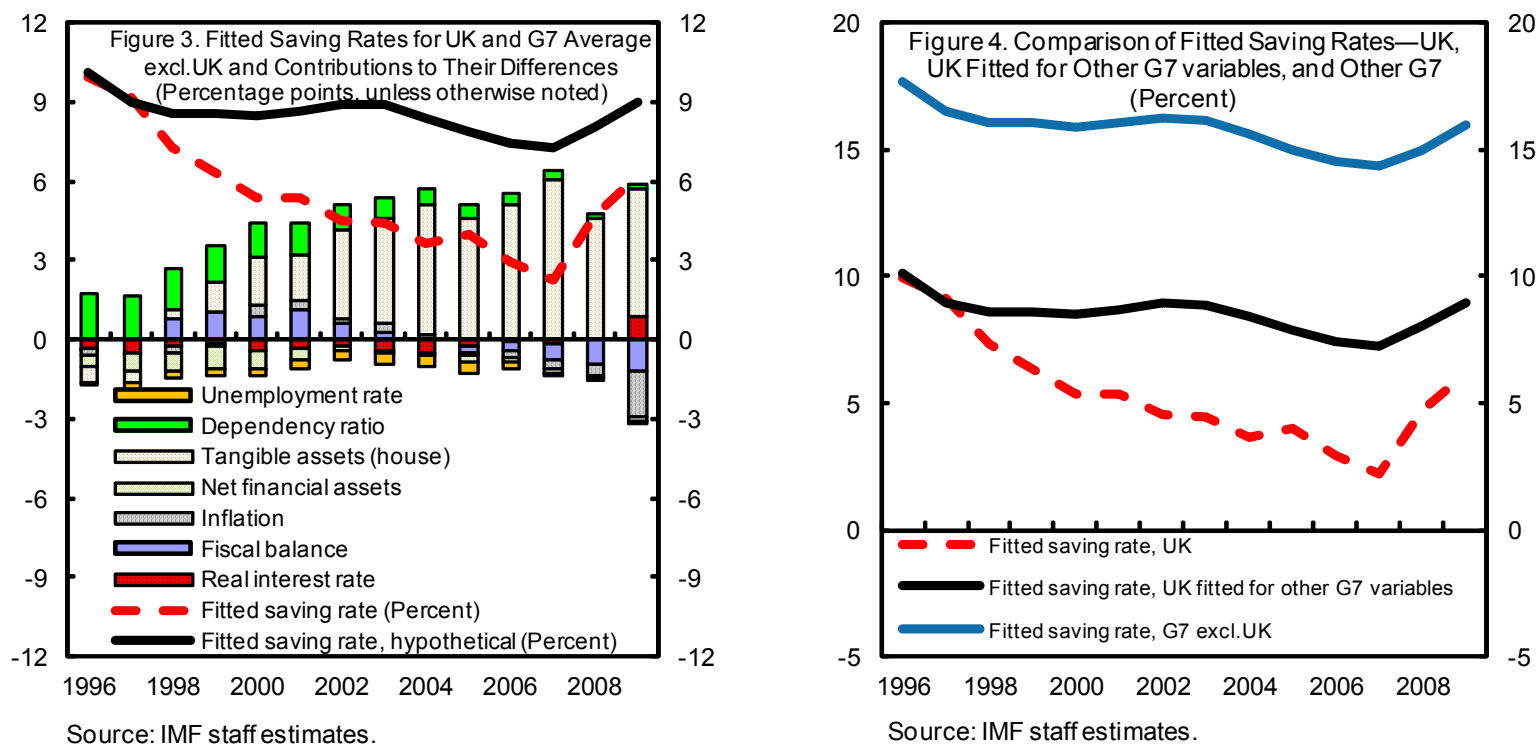

\section{E. Using the Model to Project the UK Household Saving Rate}

16. The estimated econometric model, together with assumptions on the future path of explanatory variables, can be used to project the near-term path of the household saving rate. The following assumptions for explanatory variables are used for this exercise:

- $\quad$ For the long-term interest rate, CPI inflation, the unemployment rate, and the general government overall balance, Spring 2011 WEO projections are used. ${ }^{10}$

\footnotetext{
${ }^{10}$ To derive CPI excluding effects of indirect taxes, a pass-through coefficient of 0.75 is assumed for the VAT hike in January 2011.
} 
- The dependency ratio is assumed to follow its current trend, which changes only slowly.

- $\quad$ Net financial wealth (and gross financial assets and liabilities) is assumed to remain constant in percent of gross disposable income at the 2010 level.

- The tangible wealth-to-gross disposable income ratio in 2010, for which data are not yet available, is estimated by assuming that the percent change in tangible wealth was equal to the percent change in the simple average of the Halifax house price index and the Nationwide house price index. The ratio is further assumed to decline by 48 percentage points (equivalent to a 12 percent cumulative decline in the ratio) over the six years through 2016. This projected decline balances two considerations: on the one hand, the ratio is currently about 30 percent above its historical average; this suggests that some decline in the ratio is likely going forward; on the other hand, tight planning restrictions in the UK have restrained the supply response to higher house prices; these supply constraints may keep the house price-to-income ratio from fully returning to its historical average in the foreseeable future.

\section{The resulting projections indicate that the saving rate will stay broadly flat over} the medium term, as the effects of weak house prices and fiscal consolidation offset each other (Figure 2). The ongoing multi-year fiscal consolidation will have a dampening effect on the saving rate over the projection period while the projected decline in the tangible wealth-to-gross disposable income ratio will have an offsetting upward effect. On balance, the household saving rate is projected to stay broadly flat (easing just slightly to around $4 \frac{1}{2}$ percent by 2016). ${ }^{11}$

\section{F. Implications of the Projections for Households' Balance Sheets}

\section{The household saving rate is a factor driving the dynamics of households'}

balance sheet items. In order to derive fitted out-of-sample values of the saving rate, values of net financial wealth and tangible wealth were assumed to follow particular paths over the projection horizon in the previous section. In reality, however, the saving rate also affects the pace of household net wealth accumulation. This dynamic relationship between the flow variable (saving rate) and the stock variable (household net wealth), along with influences of

\footnotetext{
${ }^{11}$ The projected saving rate is somewhat higher than the saving rate of $3 \frac{1}{2}$ percent projected by the Office for Budget Responsibility (OBR, 2011). The OBR believes that UK corporate sectors' large financial surplus will reduce needs for households to save. This effect, however, might not materialize in the medium term for a few reasons. First, it might be an optimal response for the corporate sector (and shareholders) to maintain large amounts of cash and not increase dividends in the face of continuing high uncertainty. Second, the large financial surplus might lead to a surge of investment first rather than increases in dividends. Third, while the previous two responses may still result in higher equity prices, the regression results suggest that changes in financial wealth may not have large effects on household saving.
} 
other exogenous factors on the stock variable, is described by the following law of motion of net financial wealth:

$$
N_{t}-N_{t-1}=S_{t}-\delta_{t}+C G_{t}
$$

where $N_{t}$, is net wealth at the end of period $t . N_{t}$ is defined as

$$
N_{t} \equiv F A_{t}-F D_{t}+H W_{t}
$$

$F A_{t}, F D_{t}$, and $H W_{t}$ are gross household financial assets, gross financial liabilities, and tangible wealth at the end of period $t$, respectively, while $S_{t}, \delta_{t}$, and $C G_{t}$ are household saving (a function of explanatory variables, including lagged net financial wealth and housing wealth), depreciation of tangible wealth, and net unrealized capital gains/losses (which are typically not included in gross disposable income measures from which household saving is derived) in period $t$, respectively. This equation shows that changes in the values of $F A, F D$, and $H W$ reflect four factors: (i) unrealized capital gains/losses, (ii) depreciation of tangible wealth, (iii) the saving rate, and (iv) offsetting increases in both assets and liabilities (i.e., leveraging and deleveraging). However, this equation does not necessarily imply causality running from the right-hand side of the equations to the left-hand side, as households make decisions about the desired paths of consumption/savings, assets, and liabilities simultaneously. Rather, the equation presents the way households' balance sheet evolves conditional on savings and other factors.

\section{It is convenient to rewrite the dynamics of household net wealth in terms of}

ratios to disposable income. Ultimately, households make decisions about their saving and balance sheet in relation to their disposable income levels. Changes of net wealth-todisposable income can be written as follows:

$$
\frac{N_{t}}{I_{t}}-\frac{N_{t-1}}{I_{t-1}}=\left(\frac{N_{t}-N_{t-1}}{I_{t}}\right)-\left(\frac{N_{t-1}}{I_{t-1}} \cdot \frac{I_{t}-I_{t-1}}{I_{t-1}} \cdot \frac{I_{t-1}}{I_{t}}\right)
$$

where $I_{t}$ is disposable income in period $t$. Combining this with the equation for changes in $N_{t}$ above results in the following equation:

$$
\frac{N_{t}}{I_{t}}-\frac{N_{t-1}}{I_{t-1}}=\left(\frac{S_{t}-\delta_{t}+C G_{t}}{I_{t}}\right)-\left(\frac{N_{t-1}}{I_{t-1}} \cdot \frac{I_{t}-I_{t-1}}{I_{t-1}} \cdot \frac{I_{t-1}}{I_{t}}\right)
$$

20. The dynamics of household net wealth above provide a simple cross-check for the plausibility of the saving rate projections in the previous section. As evident by the law of motion, the paths of net financial wealth, $F A_{t}-F D_{t}$, and tangible wealth, $H W_{t}$, reflect both households' saving decision (and thus their desired speed of net wealth accumulation) as well as exogenous factors (depreciation of the housing stock and capital 
gains). However, the regression model assumes that households' saving decision is affected by net financial and housing wealth, and thus the regression does not model the dynamics of asset variables as a function of the saving rate. Thus, pre-determining the paths of assets and liabilities and projecting the saving rate using the estimated model, as has been done in the previous section, amounts to making assumptions about exogenous factors driving the dynamics of the balance sheet. While the implied paths of these exogenous factors cannot be uniquely pinned down by a single equation describing the law of motion, further assumptions can be made to derive implied capital gains/losses and compare them to historical values.

\section{Implied rates of unrealized capital gains are broadly in line with historical}

averages. Using the equation describing the dynamics of the net wealth-to-gross disposable income ratio to derive implied unrealized capital gains requires assumptions on depreciation of tangible wealth and the growth rate of household disposable income:

- Projections of depreciation of tangible wealth can be based on historical data on depreciation in percent of tangible wealth. For the five-year period 2005-09, the average deprecation rate was 1.2 percent per annum.

- $\quad$ Projections of household gross disposable income growth are available in various economic outlooks. The authorities' latest projections are available from the OBR (OBR, 2011). The authorities project that real household disposable income growth will rebound to 1.4 percent in 2012 after falling slightly in 2011 and will gradually rise to 2.1 percent by 2015 . This, together with the authorities' CPI inflation projections, implies nominal disposable income growth rising gradually from 3.8 percent in 2011 to 4.1 percent in 2015.

Under these assumptions and given the equation above defining the evolution of net worth, an average unrealized capital gains return on assets of 3.5 percent during 2011-16 would equilibrate the saving rate projections in Section $\mathrm{E}$ with the assumptions on the evolution of net worth in Section E. This compares with an historical average unrealized capital gains rate of 5 percent of the stock of gross assets (this average is calculated over 1988-2010 - the period for which the current national accounts data are available). ${ }^{12}$ The fact that the implied capital gains rate is broadly comparable to the historical average indicates that assumptions underlying the saving rate projections are at least consistent with a historical benchmark, which offers a reasonable criterion to judge the appropriateness of assumptions on exogenous variables and the internal consistency of the assumptions on other variables.

\footnotetext{
${ }^{12}$ Since the liability side of households' balance sheet is largely loans, capital gains/losses derive mainly from the asset side, and the rate of gains/losses can be expressed simply in percent of gross assets.
} 


\section{G. Conclusion}

22. Empirical estimates in this chapter suggest that the UK's low household saving rate during the pre-crisis years partly reflected (i) the rapid increase in housing wealth on the back of rapid price appreciation, (ii) low real interest rates, and (iii) in the 1990s, improvements in the government fiscal balance. Looking forward, the estimation results suggest that the saving rate may stay broadly flat — easing just slightly to about $4 \frac{1}{2}$ percent by 2016 . This largely unchanged saving rate reflects the net effect of opposing forces: falling house priceto-income ratios and, to a lesser extent, rising long-term real interest rate are likely to put upward pressure on the saving rate, but this is expected to be offset by downward pressure from the ongoing fiscal consolidation. 


\section{Appendix I. Data Definitions and Sources}

\section{The definition and sources of data used in the analysis are described below:}

Saving rate $(\boldsymbol{S} \boldsymbol{A} \boldsymbol{V})$ : gross saving of households and nonprofit organizations serving households (NPISH), divided by gross disposable income of households and NPISH. Sources: OECD Analytic Database. Data for Japan are extended to 2009 using data from Cabinet Office/Haver Analytics; data for Germany are extended to 1970-90 using IMF World Economic Outlook (WEO).

Dependency ratio (DEP): population of children (14 years and below) and elderly (65 years and up) in percent of total population. Sources: World Bank World Development Indicators (WDI). Data are extended to 2008-09 using the following: Eurostat for European countries; Census Bureau/Haver Analytics for US; total population growth rates from OECD Analytic Database for Canada; and the elderly population growth rate in 2008 from WDI for Japan.

General government balance in percent of GDP ( $G G B$ Y): Sources: WEO for Canada, Japan, UK, and US; Eurostat for France, Germany, and Italy.

Inflation (INF): percent change in consumer price index. Sources: WEO. Data are extended back to 1969 using IMF International Finance Statistics (IFS).

Real long-term interest rate (RIRL): interest rate on the 10-year government bond deflated by CPI. Source: OECD Analytic Database.

Housing wealth $(\boldsymbol{H W})$ : tangible assets held by households and NPISH, divided by gross disposable income. Sources: NiGEM and national statistics:

Canada - 1970-2008 from NiGEM; nonfinancial assets in 2009 from Statistics Canada. France - 1971-2006 from NiGEM; nonfinancial assets in 2007-09 from INSEE.

Germany - 1971-2006 from NiGEM; extended to 2009 using house price-to-income ratio from OECD.

Italy - 1970-2006 from NiGEM; extended to 2009 using house price-to-income ratio from OECD.

Japan - 1980-2009, nonfinancial assets from Japan Statistics Bureau and Statistics Center. United Kingdom - 1970-2007 from NiGEM; total nonfinancial assets in 2008-09 from Office for National Statistics/Haver Analytics.

United States -1970-2008 from NiGEM; extended to 2009 using tangible assets from Federal Reserve Board/Haver Analytics.

Financial assets $(\boldsymbol{F} \boldsymbol{A H})$ : financial assets held by households and NPISH, divided by gross disposable income. 
Financial liabilities $(\boldsymbol{F L} \boldsymbol{H})$ : financial liabilities owed by households and NPISH, divided by gross disposable income.

Net financial wealth $(\boldsymbol{N F W H})$ : FAH minus FLH.

Data from national statistics were extracted from Haver Analytics and used as the baseline source for FAH, FLH, and NFWH, except for Canada, Italy, and Japan. To obtain maximum coverage, Italy is extended back using growth rates from the OECD non-consolidated balance sheet of households and NPISH.

Canada-1980-2009, OECD non-consolidated balance sheet of households and NPISH. France - 1978-93, OECD Analytic Database; 1994-2009, Banque de France/Haver Analytics.

Germany - 1991-2009, Deutsche Bundesbank/Haver Analytics.

Italy - 1975-94, OECD Analytic Database; 1995-2009, OECD non-consolidated balance sheet of households and NPISH.

Japan - 1980-2009, Japan Statistics Bureau and Statistics Center.

United Kingdom - 1970-2000, Office for National Statistics Economic and Labour Review Vol. 2, No. 4, April 2008; 2001-09, Office for National Statistics/Haver Analytics. United States - 1970-2009, Federal Reserve Board/Haver Analytics. 


\section{REFERENCES}

Barrell, R. and P. Davis, (2007), "Financial Liberalization, Consumption and Wealth Effects in Seven OECD Countries", Scottish Journal of Political Economy, Vol. 54, No. 2, pp. 254-67.

Berry, S., R. Williams, and M. Waldron, (2009), "Household Saving," Bank of England Quarterly Bulletin, 2009 Q3, pp. 191-201.

Byrne, J. and P. Davis, (2003), "Disaggregate Wealth and Aggregate Consumption: an Investigation of Empirical Relationships for the G7," Oxford Bulletin of Economics and Statistics, Vol. 65, No. 2, pp. 197-220.

Carroll, C., (2001), "The Theory of the Consumption Function, with and without Liquidity Constraints," Journal of Economic Perspectives, Vol. 15, No. 2, pp. 23-45.

Hüfner, F. and I. Koske, (2010), "Explaining Household Saving Rates in G7 Countries: Implications for Germany," OECD Economics Department Working Papers, No.754.

Jump, G., (1980), "Interest Rates, Inflation Expectations, and Spurious Elements in Measured Real Income and Saving," American Economic Review, Vol. 70, No. 5, pp. 990-1004.

Ludwig, A. and Sløk, T, (2002), "The Impact of Changes in Stock Prices and House Prices on Consumption in OECD Countries," IMF Working Paper, No.02/01.

McKinsey Global Institute, (2010), "Debt and Deleveraging: The Global Credit Bubble and Its Economic Consequences," McKinsey \& Company (New York).

Slacalek, J., (2009), "What Drives Personal Consumption? The Role of Housing and Financial Wealth," The B.E. Journal of Macroeconomics Topics, 9(1), Article 37.

Sarantis, N. and C. Stewart, (2001), "Saving Behaviour in OECD Countries: Evidence From Panel Cointegration Tests," The Manchester School Supplement 2001, pp. 2241.

IMF, (2010), "Prospects for the U.S. Household Saving Rate," IMF Country Report, No. 10/248 (Washington, D.C.). 


\section{Vulnerabilities of Household and CoRporate Balance SHEETS ANd Risks FOR THE FINANCIAL SECTOR ${ }^{1}$}

\section{A. Introduction}

1. The crisis and post-crisis recovery profoundly affected UK household and corporate sector balance sheets. Although the process of balance sheet repair is well underway, pockets of vulnerability remain in both sectors, particularly in commercial real estate, unsecured household debt, and some segments of the mortgage debt market. Stress in these segments - triggered by a rapid increase in interest rates, an increase in unemployment, a sharp decline in real estate prices, or a combination thereof-could have a significant impact on the banking sector, both directly and indirectly through feedback loops between the real and financial sectors. Concentration of credit risks in some large banks and widespread exercise of lender forbearance aggravate these vulnerabilities.

2. This chapter explores these issues by reviewing the experience of the crisis, assessing the current state of corporate and household balance sheets, and gauging the quantitative impact of risks using sensitivity analysis and contingent claims analysis. It finds that the household sector is vulnerable to increases in interest rates and income shocks, but loan losses in the banking sector from such shocks appear manageable. However, large declines in house prices could result in a greater threat to banks' asset quality, particularly if combined with a shock that impairs household debt service capacity. The corporate sector appears relatively resilient to macroeconomic shocks. One important exception is the commercial real estate sector, which is still recovering from the crisis.

\section{B. Household and Financial Sector Linkages}

\section{High household indebtedness raises} concerns about mortgage credit risk and the stability of the financial system, particularly if interest rates or unemployment were to rise or house prices were to fall further. This section documents developments in the household sector during the crisis and recovery and assesses the potential risks to the banking sector emanating from household debt using micro-level data.

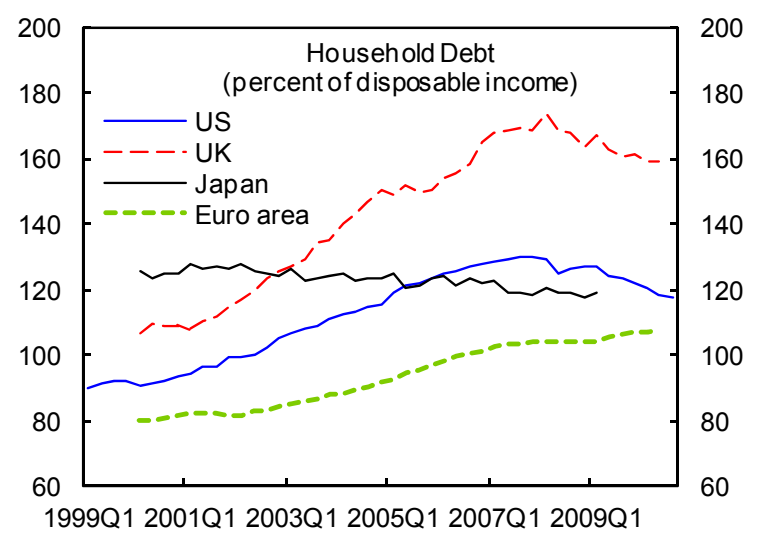

Sources: OECD; WEO; and IMF staff calculations.

\footnotetext{
${ }^{1}$ Prepared by Marta Ruiz-Arranz (EUR) with research assistance from Stephanie Denis (EUR). This chapter has also been used as technical background for the IMF's 2011 Financial System Stability Assessment (FSSA) update for the UK.
} 


\section{Developments During and After the Crisis}

\section{In the run-up to the crisis, household debt reached $\mathbf{1 7 5}$ percent of disposable}

income, fueled by rapid mortgage lending. Household indebtedness increased faster in the UK than in the US or the euro area as a whole. The rise in debt was matched by an increase in the value of housing as well as of pension funds and other financial assets held by households (Figure 1). Indeed, the asset side of household balance sheets increased faster than total debt, leading to a rapid growth in net worth.

Figure 1. United Kingdom: Household Sector, 2000-10
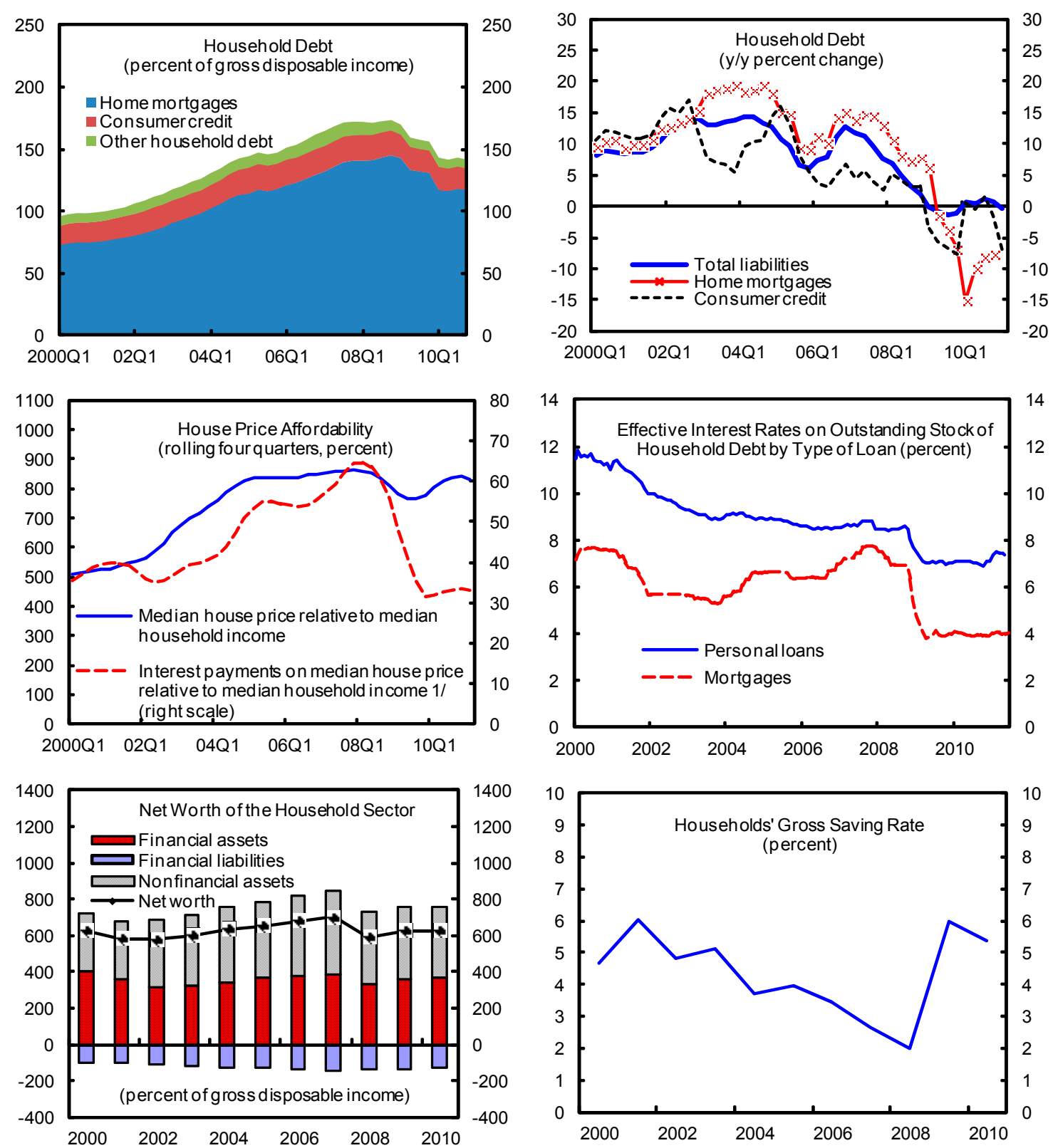

Sources: Haver Analytics; Land Registry; Department for Work and Pensions' HBAI Report; and IMF staff estimates.

$1 /$ Based on standard variable rate mortgage. 
5. UK household balance sheets were hard hit by the crisis and the deleveraging of the sector was a key feature of the downturn. Private consumption declined sharply as households responded to mounting economic uncertainty and plunging asset prices. The fall in home values and equity prices resulted in a substantial decline in net worth. This loss of net worth helped stimulate increases in savings among households striving to rebuild their wealth. The gross saving rate surged to a peak of 7.5 percent in mid-2009-up six percentage points from its pre-crisis levels.

6. Several factors cushioned the impact of the crisis on household balance sheets, averting a more severe adjustment. These included (i) record low interest rates and dominance of variable mortgage rates, which boosted debt affordability; (ii) forbearance and restructuring of loans by banks, which contained the increase in foreclosures (Figure 2); and (iii) the relatively limited rise in unemployment compared to other countries and previous recessions.

Figure 2. Household Balance Sheets and Mitigating Factors during the Crisis
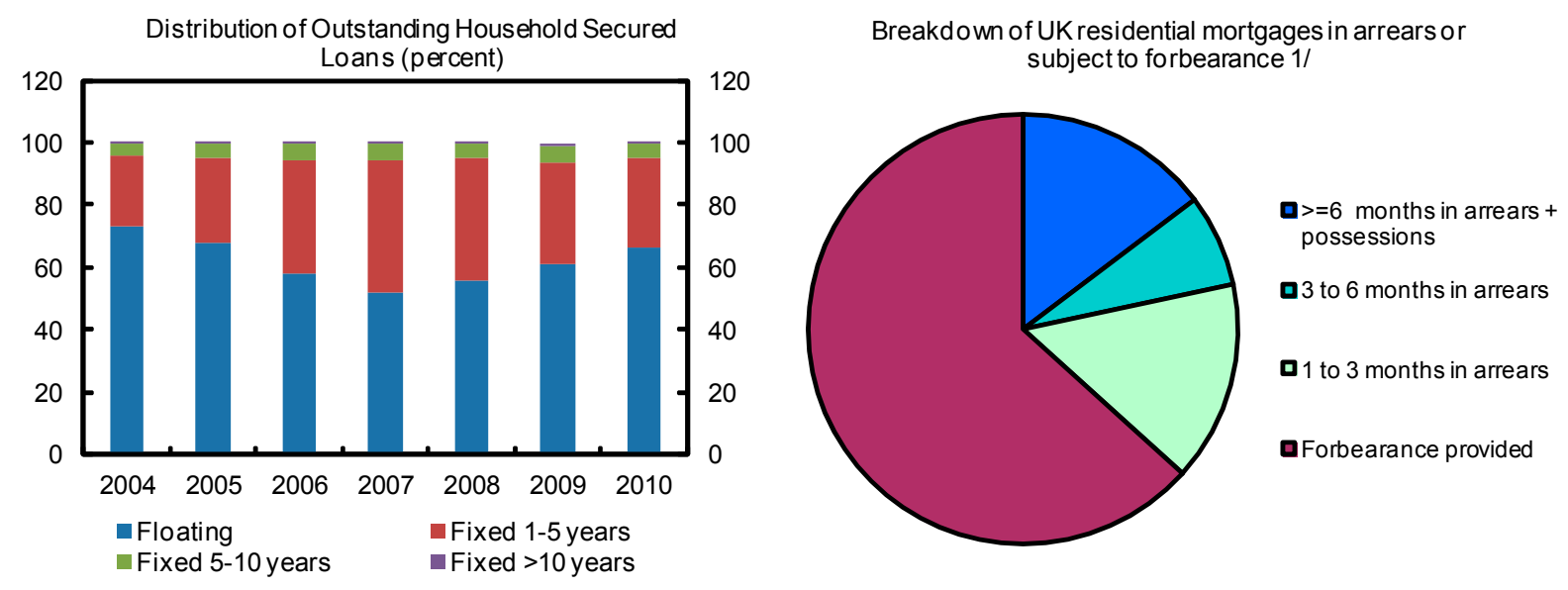

Source: Bank of England, FSA Prudential Risk Outlook, March 2011.

1/Arrears figures as of december 2009. The forbearance figure represents the number of changes made to mortgage contracts in the twelve months to March 2010.

\section{Nonetheless, the stress on household balance sheets had an impact on banks'}

asset quality. Household lending accounts for three-quarters of UK banks' domestic lending, most of which is secured against collateral. Write-off rates on secured lending to households increased a little, but write-off rates on unsecured lending have risen close to 7 percent, up 2.5 percentage points since 2008. Mortgage arrears and repossession rates have also increased, albeit by less than in previous crises and relative to the US (Figure 3). Higher default rates on US mortgages may partly reflect US bankruptcy laws, which make mortgage defaults less costly to households than in the UK. Another possible explanation is the significantly lower use of mortgage securitization in the UK, which has facilitated loan restructuring, as loans have tended to remain in the banks' books. 
Figure 3. United Kingdom: Household Sector Write-Off Rates and

Nonperforming Loans
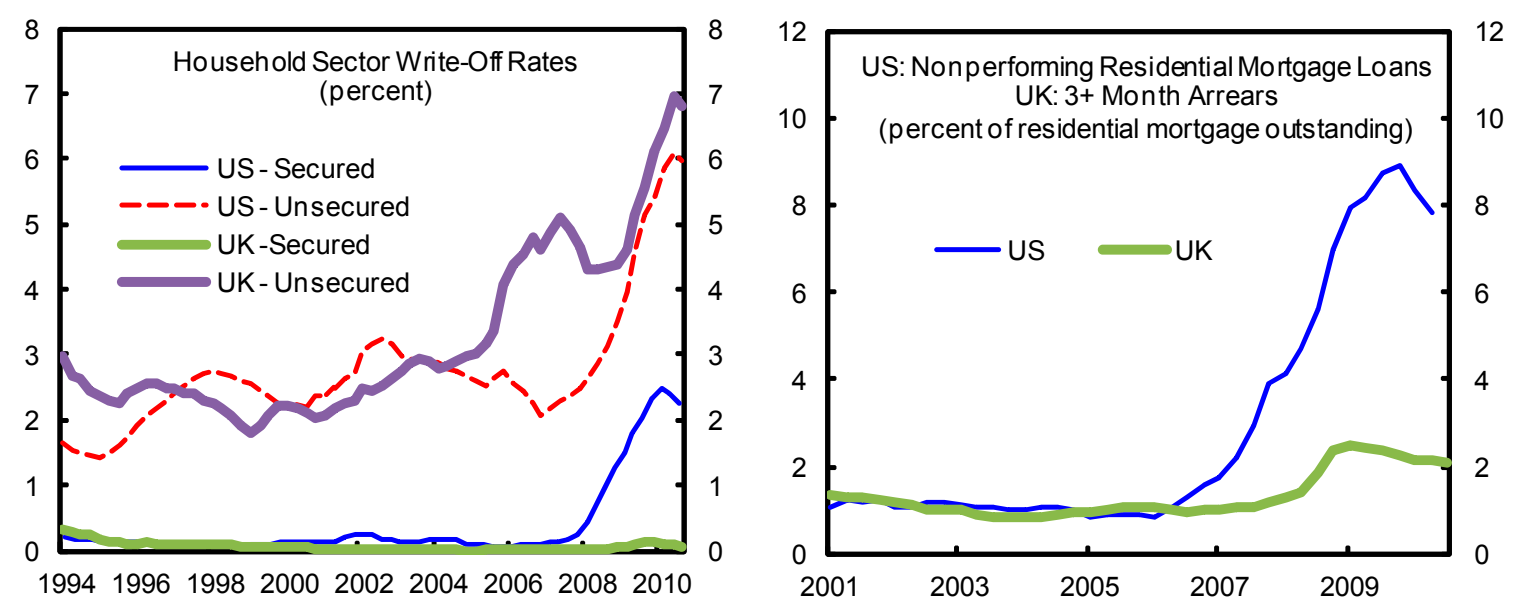

Sources: NY Fed; Bank of England; and Council of Mortgage Lenders.

\section{Looking Forward: Household Sector Risks in the Recovery}

\section{Despite significant deleveraging, household balance sheets remain fragile in the}

UK. Though off its peak, household debt remains high by historical and international standards. Its onerous impact has been mitigated to some extent by a build up of household sector currency and bank deposits since the second half of 2010. Higher saving rates have the potential to generate enough financial surpluses to reduce household indebtedness. However, the saving rate already fell back to 5.3 percent in 2010 from its peak of 7.5 percent in mid2009 , as recovering asset prices and a stabilizing labor market lifted confidence in 2010, slowing the pace of balance sheet repair.

\section{Housing valuations continue to appear stretched relative to income and rents,} leaving banks exposed to further falls in housing prices. After falling by 20 percent since their peak in 2007, house prices staged a faster-than-expected recovery in 2009 and the first half of 2010. The upward momentum has since dissipated, with the three-month change in house prices turning negative, and surveys point to continued downward pressure on prices. Overall, prices remain about 15 percent below their peak in 2007. At this level, the price-toincome ratio and price-to-rent ratio remain 30 percent above historical averages (Figure 4). It is worth noting that supply constraints are likely to prevent house prices from fully falling back to their historical averages. ${ }^{2}$

\footnotetext{
${ }^{2}$ Other factors affecting real house prices are discussed in Sá and others (2011).
} 
Figure 4. United Kingdom: Housing Developments
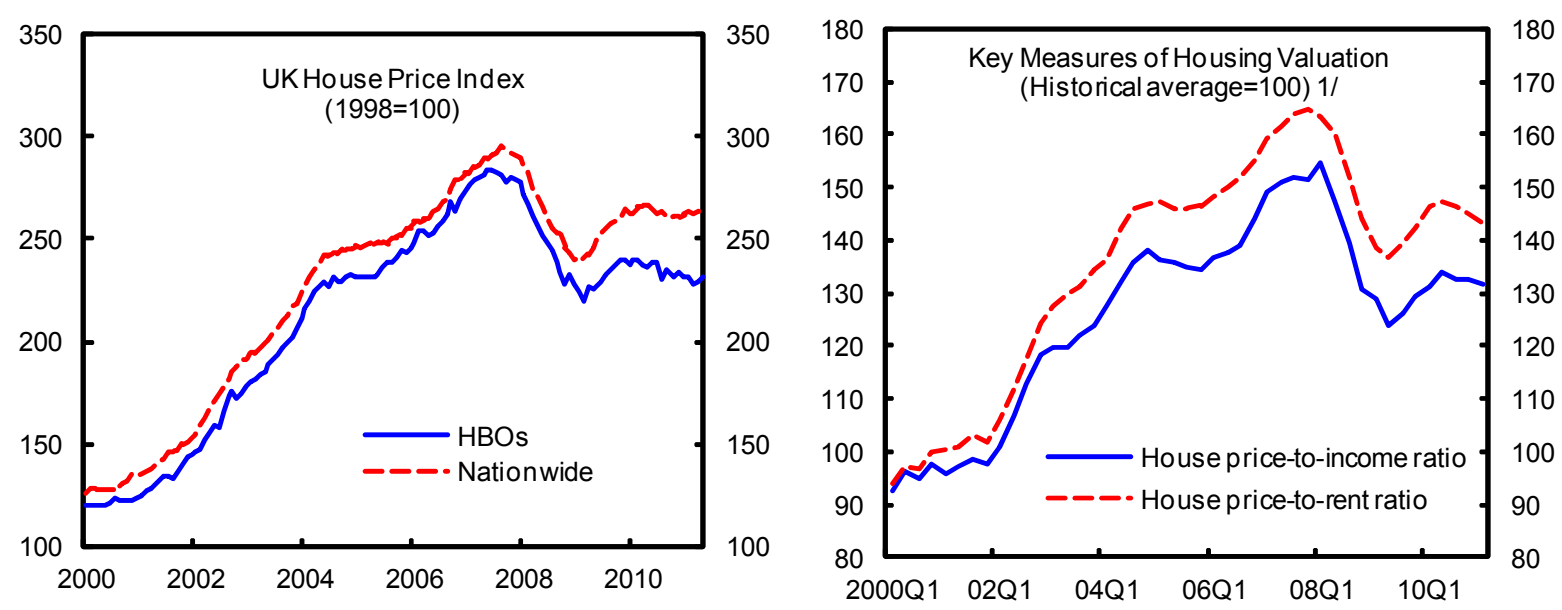

Sources: CML Research; Haver Analytics; OECD; and IMF staff calculations.

1/Historical average refers to the period 1970Q1-2011Q1.

10. Some segments in the mortgage debt market appear vulnerable and represent yet another source of credit risk for banks. Although overall arrears and repossessions have so far remained contained, they are concentrated in some groups of risky borrowers. In particular, arrears rates are higher for borrowers with high loan-to-value (LTV) loans and with buy-to-let loans, as these may reflect a higher share of second mortgages than owner-occupied mortgages (Financial Services Authority, 2011). There

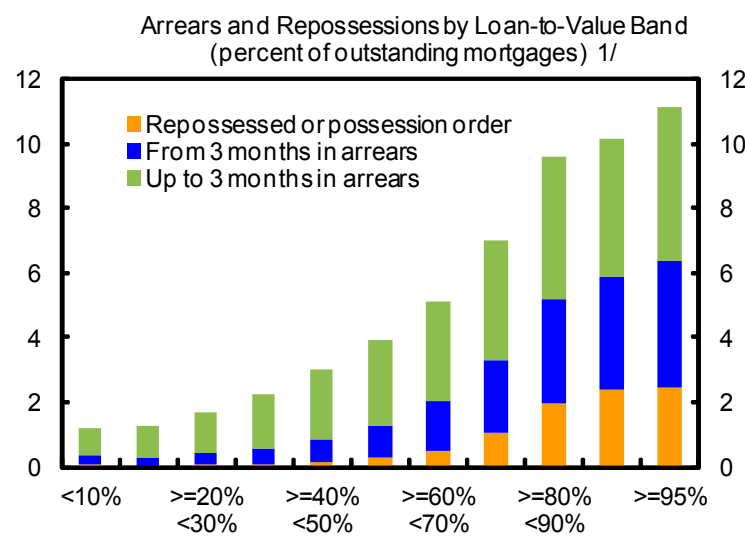

Sources: FSA Product Sales Database; and Arrears Database. 1/Performance as of August 2009 of mortgages sold between April 2005 and March 2009.

are also regional variations: arrears in the North and in Wales, which experienced large house price declines and a slower housing market recovery, are significantly higher than in other regions.

\section{Write-offs on unsecured lending have kept rising, posing further risks to banks.}

Although unsecured lending accounts for less than 10 percent of total loans, absolute losses from unsecured debt have so far surpassed losses from mortgage defaults. As reported in the most recent Credit Conditions Survey (Bank of England, 2011a), spreads on unsecured lending continue to widen (as banks appropriately price in the higher risk of default), and unsecured debt payments, notably on credit cards, have been rising as a share of household income despite the fall in policy rates. There has been, however, some recent improvement in the appetite for unsecured credit risk on the part of lenders. Evidence from the $2010 N M G$ Consulting Survey confirmed that households' financial position remains under strain (Nielsen and others, 2010). Households report that the burden of unsecured credit was higher and concerns about the debt level have increased, particularly among high LTV mortgagors. 
The survey also points to increased difficulties in keeping up with bills and credit commitments, and a marked concern about the impact of fiscal consolidation measures.

\section{Furthermore, banks' own deleveraging efforts and funding pressures could} constrain credit conditions for households. ${ }^{3}$ Households remain dependent on banks for refinancing, but bank credit availability is still tight, as suggested by the Bank of England survey on credit availability (Figure 5). Mortgage approvals and net lending amounts have also stayed at low levels, and evidence from the 2010 NMG Consulting Survey shows an increase in the proportion of households reporting a tightening in credit conditions, especially among unsecured debtors and high LTV mortgagors (Nielsen and others, 2010). Lending standards have appropriately strengthened: average loan-to-value ratios on new first mortgages are around 75-80 percent, well below the ratios observed during the pre-crisis boom, which should contain potential losses given default.

Figure 5. United Kingdom: Bank Credit Availability
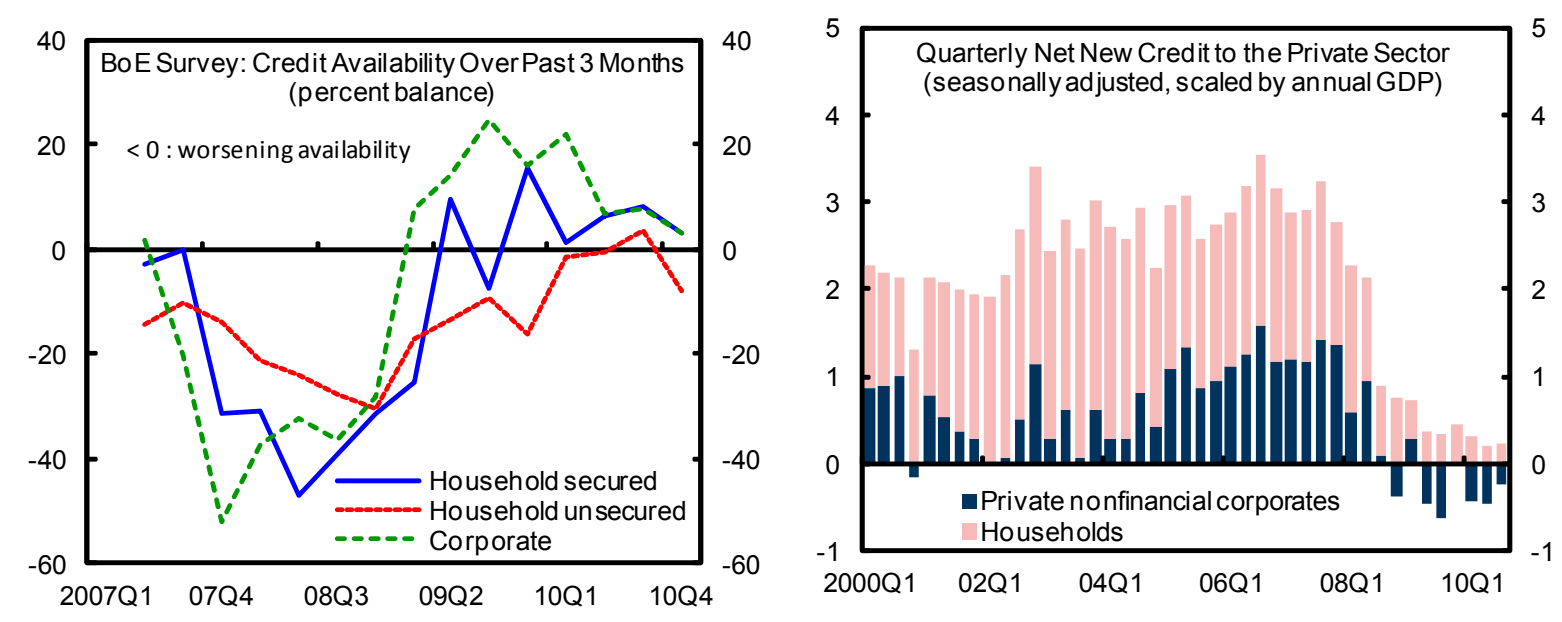

Source: Bank of England.

\section{The discussion above suggests continuing fragility that, under stress, may}

translate into credit losses in the banking system. In particular, banks would be exposed to higher defaults, were interest rates or unemployment to rise or house prices to fall. Write-offs on secured lending have so far remained contained, largely due to exceptionally low interest rates. Given the dominance of variable-rate mortgages, households' debt affordability could fall sharply if interest rates were to rise. These vulnerabilities are aggravated by the fact that risks are concentrated in some vulnerable banks with very large exposures.

\footnotetext{
${ }^{3}$ New regulatory requirements and the unwinding of policy support, including repayments to the Special Liquidity Scheme, may increase pressure on banks' balance sheets and affect credit availability.
} 


\section{Sensitivity Analysis of Household Balance Sheets}

14. This section takes a more rigorous approach to the risks discussed above and attempts to quantify some of the potential threats to financial and macroeconomic stability from household indebtedness. What happens to households' ability to pay if interest rates go up or unemployment rises? How many households will end up with negative equity if house prices fall further? What would be banks' credit losses in these scenarios?

\section{This exercise uses micro data to analyze the stability risks arising from}

household indebtedness. The scope for using aggregate data from the financial and national accounts to evaluate these risks is limited, as such data do not provide information regarding the distribution and matching of debt, interest expenditures, income, and assets. More granular data regarding individual households may reveal pockets of vulnerability in the household sector. This study uses data from the September 2010 NMG Consulting Survey of UK households. ${ }^{4}$ The survey provides balance sheet information (secured and unsecured debt, housing, and financial assets), as well as data on income, debt expenditures, and selfreported indicators of financial stress (e.g., ability to meet payments).

\section{One rough measure of the risks in household lending is the distribution of}

household debt across income categories. In principle, the smaller the share of debt held by lower-income households, the lower the risks associated with household lending. As expected, high-income households hold the larger share of total household debt, especially mortgage debt. However, low-income households' share of unsecured debt is more than commensurate to their income. ${ }^{5}$ The descriptive statistics in Table 1 also point to other potential sources of vulnerability. The median low-income household has significantly higher mortgage debt-to-income and debt mortgage payments-to-income ratios than other income categories. This suggests that low-income households' ability to service their debt could be compromised under financial stress, leading to credit losses for

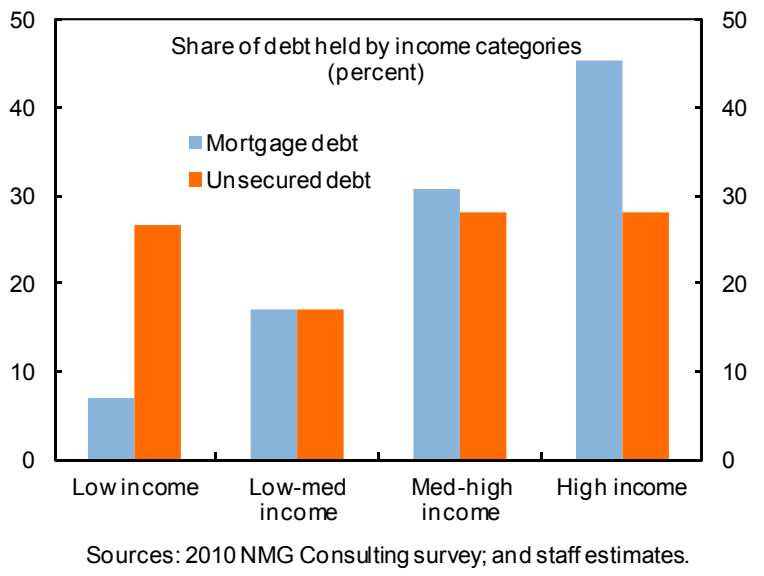
the banking sector.

\footnotetext{
${ }^{4}$ The survey covers about 2000 households. Sampling techniques attempt to make the sample representative of the population. See Nielsen and others (2010).

${ }^{5}$ Income groups are defined as follows: low-income: gross annual income up to $£ 17,500$; low-medium income: $£ 17,500-£ 35,000$; medium-high income: $£ 35,000-£ 60,000$; and high income $>£ 60,000$.
} 
Table 1. Descriptive Statistics by Income Category 1/

(average value)

\begin{tabular}{lcccc}
\hline & $\begin{array}{c}\text { Low } \\
\text { income }\end{array}$ & $\begin{array}{c}\text { Low-med } \\
\text { income }\end{array}$ & $\begin{array}{c}\text { Med-high } \\
\text { income }\end{array}$ & $\begin{array}{c}\text { High } \\
\text { income }\end{array}$ \\
\hline Mortgage debt-to-income ratio & 481.0 & 296.6 & 223.5 & 169.8 \\
Mortgage payments to income & 36.9 & 23.0 & 17.6 & 12.9 \\
Unsecured debt-to-income ratio & 40.8 & 20.9 & 20.7 & 12.1 \\
Unsecured debt payments to income & 12.7 & 10.4 & 7.7 & 4.6 \\
\hline
\end{tabular}

Sources: 2010 NMG Consulting survey; and staff estimates.

$1 /$ Income groups are defined as follows: low-income: gross annual income up to $£ 17,500$; low-medium income: $£ 17,500$ - $£ 35,000$; med-high income: $£ 35,000-£ 60,000$; and high income $>£ 60,000$.

17. Three stress scenarios are considered: an increase in interest rates of 300 basis points (well above the 60-65 basis points rise in interest rates assumed in the solvency stress test of the banking sector conducted as part of the IMF's FSSA exercise), a decline in household income of 20 percent, and a decline in house prices of 20 percent (in line with the FSSA solvency stress test of the banking sector). These are severe (low probability/high impact) stress scenarios. To put them in perspective, it is worth noting that SONIA futures suggest a rise of less than 50 basis points in rates within a year. IMF staff's central scenario assumes a reduction in the house price-to-income ratio of around 12 percent over the medium term (implying small increases in nominal house prices given rising nominal incomes).

\section{To assess the impact of these shocks, a mortgagor household is defined to be financially stressed if its mortgage debt service-to-income ratio (DSI) is larger than a} certain threshold. The stress threshold is defined as a DSI of 40 percent of income. This threshold is higher than many used in the literature, but the purpose is to identify the truly vulnerable households. ${ }^{6}$ In addition, two other thresholds were considered as a robustness check, but the results were essentially the same. ${ }^{7}$ The left-hand side panels of Figure 6 show the distribution of household DSI ratios by income groups relative to each of the three stress thresholds under consideration. This gives an indication of how many households in each

\footnotetext{
${ }^{6}$ May and Tudela (2005) find that a DSI ratio of 20 percent or above is associated with a higher probability of mortgage payment problems in England. For Austria, Beer and Schurz (2007) define financially distressed households as those that have a DSI ratio above 30 percent. This note uses thresholds as in Karasulu (2008).

${ }^{7}$ The two alternative thresholds are (i) two standard deviations of the average DSI within each income group; and (ii) two standard deviations of the average DSI of mortgagors reporting difficulties in paying for their mortgage (a self-reporting measure of financial distress). Results from the sensitivity analysis are similar under the three alternative measures. However, the distributional implications are different, with the uniform threshold identifying a larger number of low-income financially stressed households than the other two measures.
} 
Figure 6. United Kingdom: Household Debt Service-to-Income (DSI) Ratio, by Income Groups (percent $y$-axis; DSI $x$-axis)
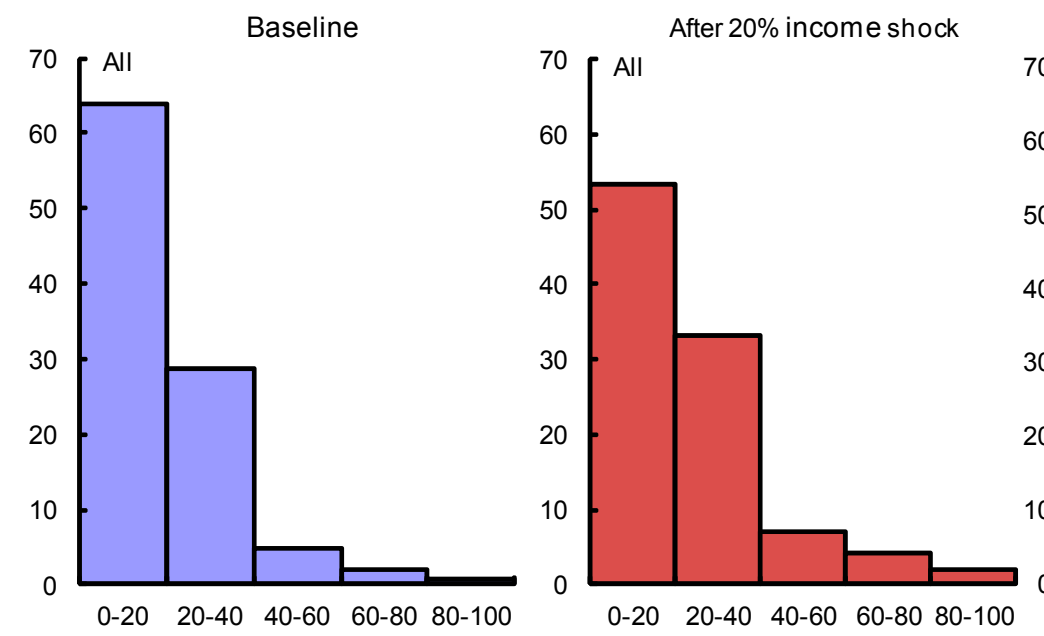

After 300bps interest rate shock
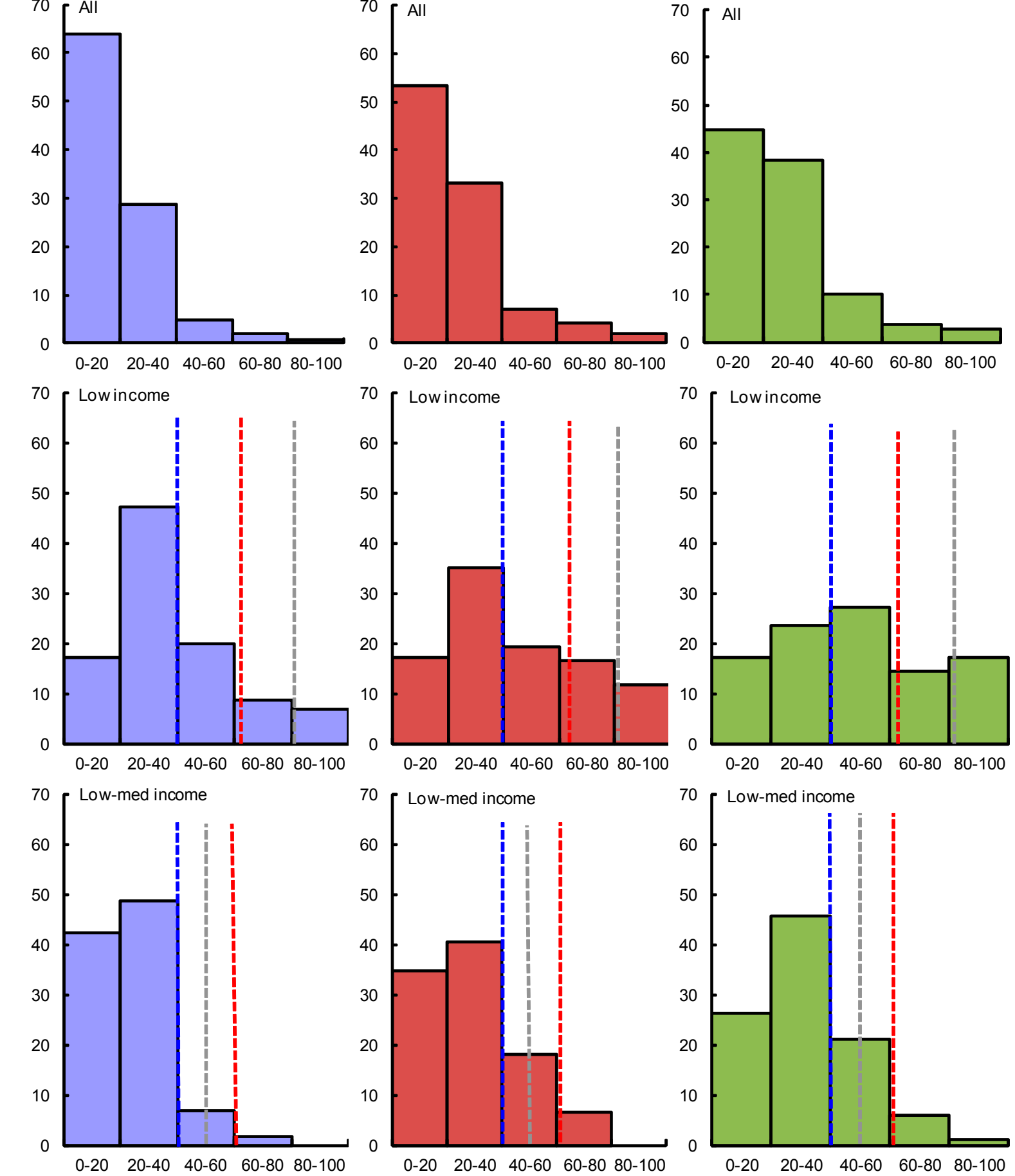

Sources: UK Household Survey; and IMF staff calculations.

Note: Each vertical dotted line represents a DSI threshold., i.e. T1 (blue); $\mathrm{T} 2$ (red); $\mathrm{T} 3$ (gray). Lowincome: $\mathrm{T} 1=40, \mathrm{~T} 2=62, \mathrm{~T} 3=81$. Low-med income: $\mathrm{T} 1=40, \mathrm{~T} 2=61, \mathrm{~T} 3=50$. Med-high income: $\mathrm{T} 1=40, \mathrm{~T} 2=50 \mathrm{~T} 3=43$. High income: $\mathrm{T} 1=40, \mathrm{~T} 2=25, \mathrm{~T} 3=26$. 
Figure 6. United Kingdom: Household Debt Service-to-Income (DSI) Ratio, by Income Groups (percent $y$-axis; DSI $x$-axis), Continued
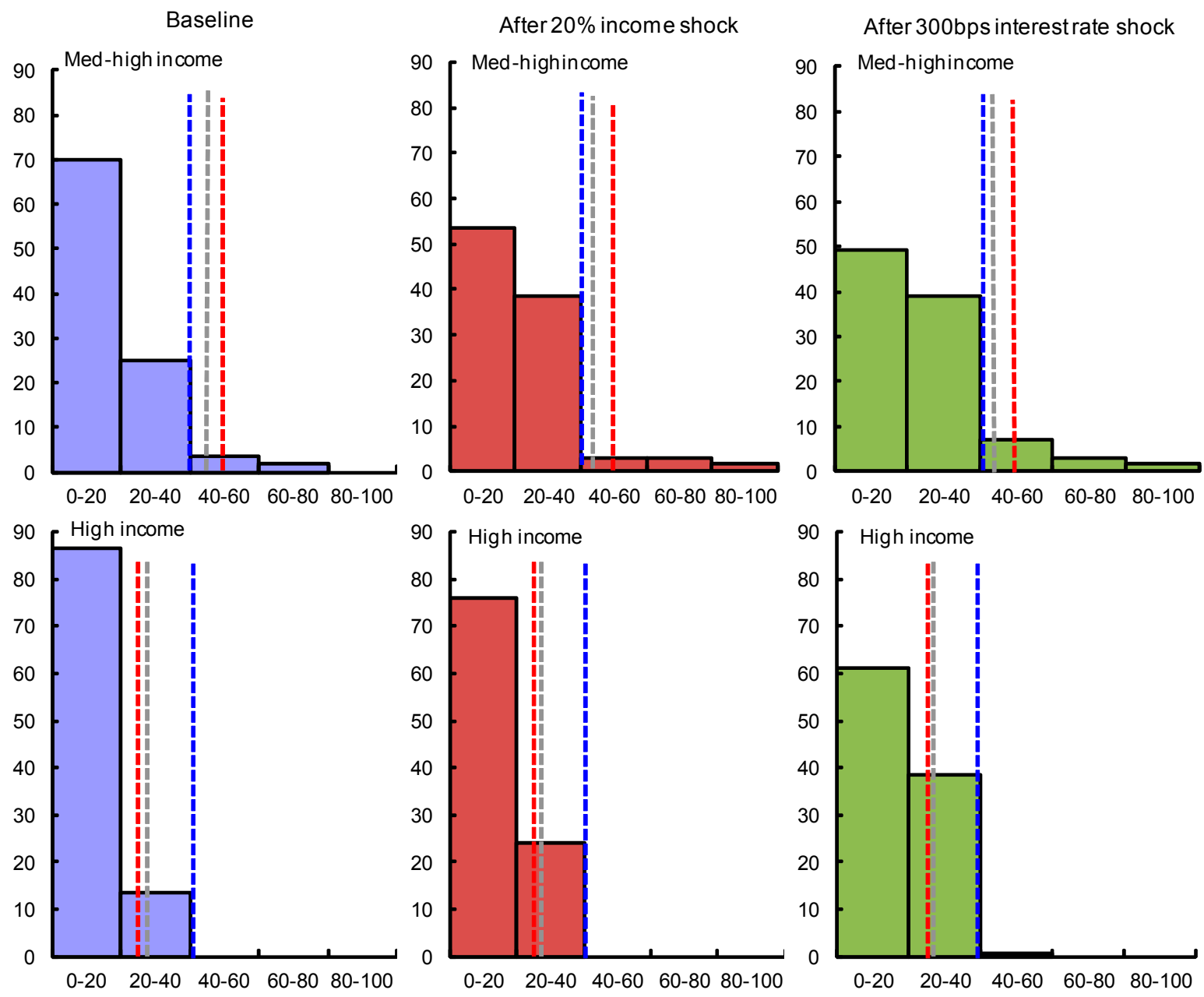

Sources: UK Household Survey; and IMF staff calculations.

Note: Each vertical dotted line represents a DSI threshold., i.e. T1 (blue); T2 (red); T3 (gray). Low income : T1 = 40, T2 = 62, T3 = 81. Low-med income: T1=40, T2 =61, T3 = 50. Med-high income: T1 =40, T2 = 50 T3=43. High income: T1 = 40, T2= 25, T3 = 26.

income category are below the stress threshold and how close the other households are to it. In 2010, about 35 percent of low-income households had DSI ratios above 40 percent, compared to 9 percent, 5 percent, and zero percent in the higher-income categories.

19. The share of vulnerable households captures the impact of different stress scenarios on the household sector as a whole, but different indicators are needed to monitor possible bank losses. Two such indicators are used in this exercise:

- $\quad$ Since default data are not available at the household level, debt-at-risk is defined as the debt of financially stressed mortgagors. Debt-at-risk does not correspond directly to nonperforming loans; rather, it is the debt that could come under financial strain or could potentially become nonperforming. As such, debt-at-risk likely overestimates credit losses. 
- $\quad$ A loss-given-default (LGD) measures the share of debt at risk that is not covered by the household's assets (both real and financial). The intuition is that if a household defaults on its debt, the bank will only incur losses to the extent that the household's assets are not able to cover its debt. This measure, however, is likely to underestimate credit losses, as banks may not be able to repossess all assets. In addition, the estimated LGD is based on the prevailing value of the assets. In a situation of macroeconomic stress, the value of both real and financial assets is likely to fall, which means that a smaller fraction of debt would be covered by assets. Finally, this LGD measure does not take into account the potentially large transaction costs involved in defaults.

Formally,

$$
\begin{gathered}
\text { Debt at risk }=\frac{\sum_{i} S_{i} D_{i}}{\sum_{i} D_{i}}, \quad \text { where } S_{i}=\left\{\begin{array}{l}
1 \text { if } D S I_{i}>40 \\
0 \text { otherwsie }
\end{array}\right. \\
L G D=\frac{\sum_{i} S_{i} L_{i}}{\sum_{i} D_{i}}, \quad \text { where } L_{i}=\left\{\begin{array}{c}
-N W_{i} \text { if } N W_{i}<0 \\
0 \text { otherwsie }
\end{array}\right.
\end{gathered}
$$

Where $D_{i}$ is the debt of household $i$ and $N W_{i}$ is the net worth of household $i$, which is defined as the sum of household assets (real estate and financial) minus total debt (mortgage and unsecured debt). The survey provides information on households' assets and liabilities to estimate net worth.

20. The state of household balance sheets in September 2010 (date of the household survey) is the starting point for the sensitivity analysis.

- $\quad$ Eight percent of mortgagors were financially stressed in September 2010. The average DSI for financially stressed households was 58 percent, and their average mortgage debt was six times their average annual gross income (Table 2).

- $\quad$ Ten percent of total mortgage debt was at risk. With total household mortgage debt in the economy amounting to 96 percent of GDP, this means that about 10 percent of GDP worth of mortgages could come under financial strain (this is based on the presumption that the survey is representative of the population). ${ }^{8}$

- $\quad$ Estimates of loss-given-default show that most mortgage debt is covered by household assets, mostly real estate. The estimates suggest that if vulnerable

\footnotetext{
${ }^{8}$ These aggregate figures mask important differences across household income groups. The percentage of financially stressed households decreases with household income. Low-income households appear very vulnerable: over 35 percent of these households are financially stressed, and more than 50 percent of this group's total debt is at risk. However, this only represents 3.6 percent of total household sector debt.
} 
households were to default on their debts, creditors would suffer losses corresponding to 0.4 percent of total household debt.

Table 2. Sensitivity Analysis of Household Sector: Baseline, September 2010

\begin{tabular}{lcccc}
\hline & $\begin{array}{c}\text { Share of stressed } \\
\text { households in } \\
\text { each income } \\
\text { category }\end{array}$ & $\begin{array}{c}\text { Share of debt-at- } \\
\text { risk in each } \\
\text { income } \\
\text { category }\end{array}$ & $\begin{array}{c}\text { Debt-at-risk } \\
\text { (percent of total } \\
\text { household debt) }\end{array}$ & $\begin{array}{c}\text { LGD (percent of } \\
\text { total household } \\
\text { debt) }\end{array}$ \\
\hline Low-income & 35.6 & 52.4 & 3.6 & 0.0 \\
Low-med income & 8.7 & 14.1 & 2.4 & 0.3 \\
Med-high income & 5.4 & 13.7 & 4.3 & 0.1 \\
High-income & 0.0 & 0.0 & 0.0 & 0.0 \\
All & 8.2 & 10.3 & 10.3 & 0.4 \\
\hline
\end{tabular}

Sources: 2010 NMG Consulting Survey; and staff estimates.

\section{Interest rate shock}

21. The household sector is sensitive to increases in interest rates, but loan losses in the banking sector in response to this shock appear manageableat least as long as the underlying assets maintain their value. A rise in interest rates by 300 basis points would increase the share of financially stressed households to 18 percent, from 8 percent in the baseline (Figure 7). Debt-at-risk would increase by over 10 percentage points, bringing total debt-at-risk to 20 percent of GDP. The impact would be most severe among low-income households, as they tend to have high DSI ratios even before the shock. Indeed, about three-fourths of low-income household debt would be considered at risk after the shock. However, given the relatively low share of bank loans to this income group, the impact on asset quality is likely to be small (see pie chart). This shock would more than double LGD (debt-at-risk not covered by assets) compared to the baseline, to almost 1 percent of total household sector loans (about 1 percent of GDP). This low LGD estimate reflects the partial-equilibrium nature of this exercise, which assumes that the value of the underlying asset is not affected. 
Nonetheless, these results suggest that, even if household balance sheets were shocked with a 300 basis point interest rate increase, the impact on banks would be manageable.

22. These estimates represent the long-run impact of the interest rate shock. They are based on the assumption that all mortgages are affected by the interest rate increase (in the long run, even fixed-rate mortgages are affected due to renegotiation of interest rates). The short-run impact of the shock, affecting only variable-rate mortgages, would be half as large. This lower estimate should be interpreted with caution. First, the share of fixed-rate mortgages in our sample of mortgagors (almost 50 percent) is larger than the actual share in the population, which is about a third of outstanding mortgages. Second, mortgagors are currently moving from expiring fixed-rate mortgages to floating-rate mortgages (Bank of England, 2010), increasing the sensitivity of borrowers to interest rises.

Figure 7. United Kingdom: Sensitivity Analysis of the Household Sector 1/
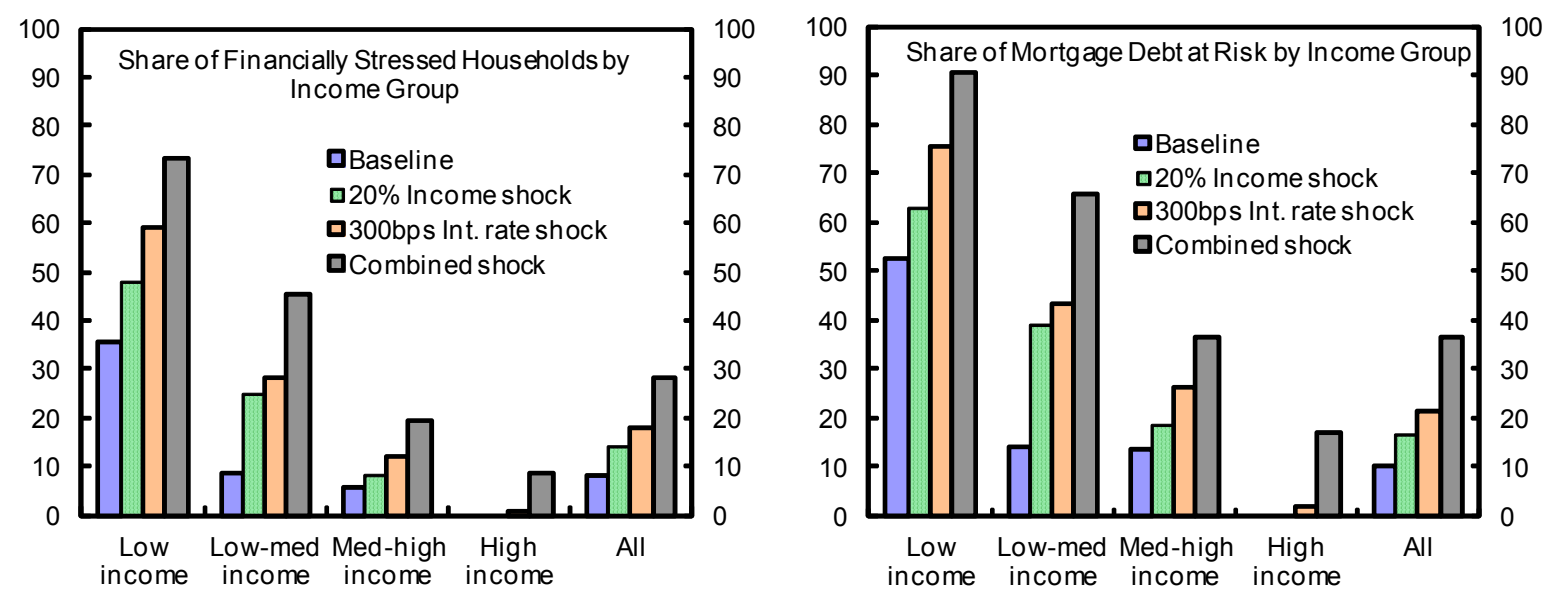

Sources: 2010 NMG Consulting Survey;and IMF staff estimates.

$1 /$ Financially distressed households are defined to have mortgage debt service above 40 percent of income.

\section{Income shock and combined interest rate-income shock}

\section{Similarly, income shocks would significantly affect individual households, but}

may not necessarily generate large bank losses. A drop in income by 20 percent would increase the share of vulnerable households to 14 percent (Figure 7). Debt-at-risk would rise by 6 percentage points of GDP, and LGD would reach almost 1 percent of total loans. Again, this shock would disproportionately affect low-income households. However, since they account for a relatively small proportion of total bank mortgage lending, the impact on bank asset quality is likely to be limited. This shock is indicative of the risks were unemployment to rise beyond current rates or the economy to slow down. In contrast, a combined interest rate and income shock could have a major impact on household balance sheets, and thus the potential to inflict larger losses on the banks. 


\section{Housing price shock}

\section{Further declines in house prices would affect households' net worth, and banks'}

LGD under such a scenario may be sizeable. Furthermore, with less home equity available, homeowners would have fewer options to refinance existing mortgage debt or take on new debt that could be used to pay off other debt contracted at higher rates. Since house price shocks do not directly affect household debt service payments, an alternative measure of financial stress is needed to assess the sensitivity of households to falls in house prices. One such measure is based on household net worth. Households whose net worth becomes negative are considered financially stressed. By associating financial stress to wealth, this measure attempts to capture the ability of households to liquidate assets (or pledge

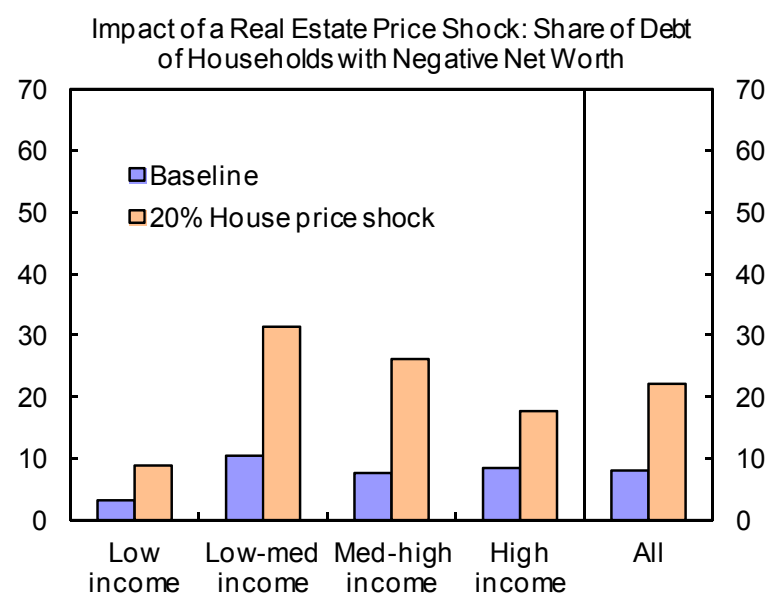

Sources: 2010 NMG Consulting Survey; and IMF staff estimates. real estate assets) in order to service debt before default. By late 2010, less than 6 percent of households, accounting for about 8 percent of total household debt (mortgage and consumer debt) had negative net worth. After a 20 percent house price drop, about 16 percent of households would have negative net worth, pushing debt at risk to 22 percent of the total. Potential losses for banks as measured by LGD would climb to 4 percent of all household loans. Tellingly, arrears in the North and Wales, which experienced large house-price declines and a slower housing market recovery, are higher than in other regions. This also suggests that a combined shock that affects both household debt service capacity — such as an increase in unemployment - and the collateral value of secured debt could have a material impact on asset quality. A mitigating factor, nonetheless, is that, unlike in the US, mortgagors in the UK have historically tended to service their mortgages, even during the worst of times, in part because of a greater willingness on the part of banks to restructure loans in order to maintain debt affordability and in part because mortgage bankruptcy law is less lenient to defaulters in the UK than in the US. 
Table 3. Sensitivity Analysis of Household Sector: Summary of Shocks

\begin{tabular}{lccc}
\hline & $\begin{array}{c}\text { Share of stressed } \\
\text { households in } \\
\text { each income } \\
\text { category }\end{array}$ & $\begin{array}{c}\text { Share of debt-at- } \\
\text { risk (percent of } \\
\text { total household } \\
\text { debt) }\end{array}$ & $\begin{array}{c}\text { LGD (percent of } \\
\text { total household } \\
\text { debt) }\end{array}$ \\
\hline Baseline & 8.2 & 10.3 & 0.4 \\
Interest rate shock & 17.8 & 21.5 & 0.9 \\
Income shock & 14.1 & 16.7 & 0.9 \\
Housing price shock & 15.6 & 22.1 & 4.0 \\
Combined intrest rate and & 28.4 & 36.4 & 0.9 \\
income shock & & &
\end{tabular}

Sources: 2010 NMG Consulting Survey; and staff estimates.

\section{Unsecured debt}

\section{The burden of unsecured credit} could increase further were interest rates to rise or income to decline. About 26 percent and 23 percent of total unsecured debt would become at risk following a 20 percent negative income shock and a $300 \mathrm{bps}$ interest rate rise, respectively. This would represent about 5 percent and 4.5 percent of GDP, respectively, of potential default losses, given that total unsecured debt was 20.5 percent of GDP at end-2010. These estimates assume a stress threshold of unsecured debt service payments-to-income of 20 percent.

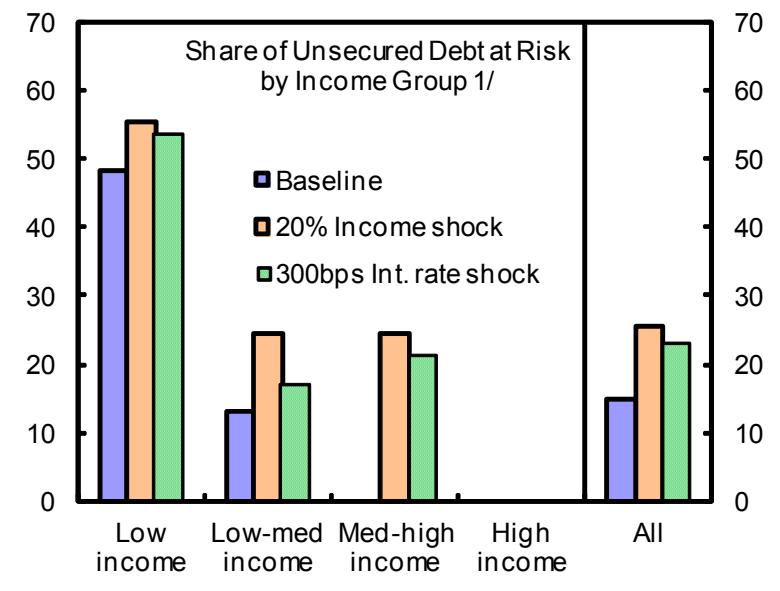

Sources: 2010 NMG Consulting survey; and staff estimates. $1 /$ Financially stressed households have un secured debt service payments above 20 percent of income.

\section{Corporate and Financial Sector Linkages}

26. This section discusses how the nonfinancial corporate sector was affected by the crisis and the recovery. It goes on to assess how vulnerable the corporate sector is, going forward, using two different methodologies. Contingent claims analysis is used to estimate expected losses from corporate defaults one year from now. And sensitivity analysis is used to assess how corporate balance sheets would be affected by interest rate and profitability shocks. The results suggest that the corporate sector as a whole remains relatively resilient to shocks, but there is significant variation across sub-sectors. 


\section{Developments During and After the Crisis}

\section{The UK nonfinancial corporate sector weathered the financial crisis relatively}

well. Firms entered the crisis with relatively solid financial balances, despite high debt levels. As demand and profits contracted and the outlook deteriorated, firms cut back on investment to preserve cash flow. Still, the increase in the number of company liquidations during the crisis was moderate compared to previous crises and has been declining since late 2009. Low interest rates and bank restructuring have helped companies avoid default (Figure 8).

Figure 8. United Kingdom: Nonfinancial Corporate Sector
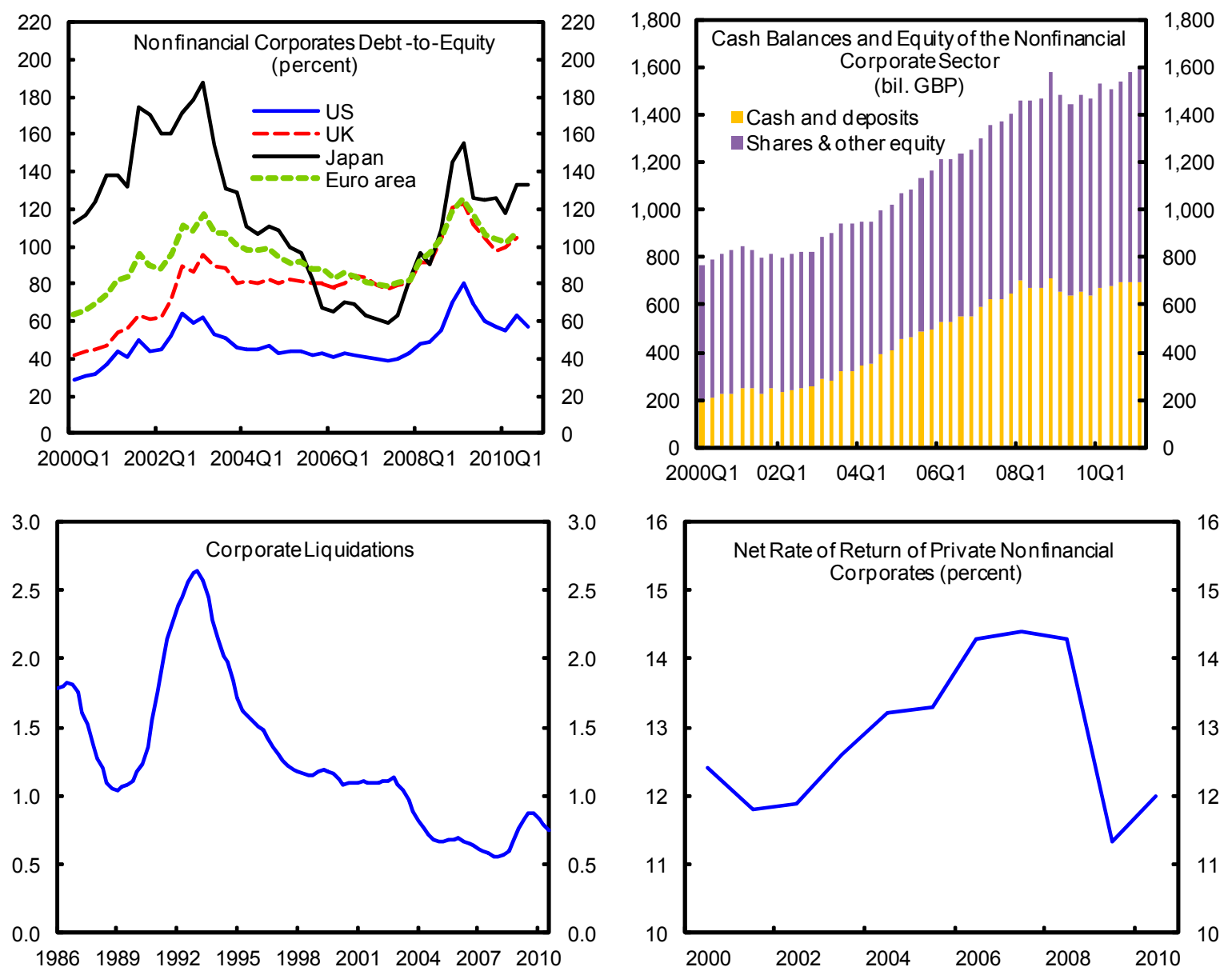

Sources: Bank of England; Office for National Statistics; and IMF staff calculations.

\section{Corporate sector balance sheets have strengthened over the last year, along} with the rest of the economy. Debt represents about half of the total sources of funding for UK nonfinancial corporate (Figure 9). The crisis triggered deleveraging and changes in the composition of debt financing away from bank debt. Since the crisis, leverage ratios have continued to trend downwards, corporate profitability has increased, and investment has rebounded. Corporate bond spreads are back to pre-crisis levels and equity prices have been rising. A key indicator of firms' viability, the interest cover ratio, has also recovered. The 
interest cover ratio (ICR) measures the degree to which cash flows are sufficient to cover interest on debt. Firms where earnings before interest and taxes are less than interest payments due (i.e., the ICR is less than one) are vulnerable and their debt is considered "at risk." They can survive by selling assets to meet their obligations, but this is not sustainable over the long term. Just before the crisis, one-third of listed companies in the Worldscope database had ICRs of less than one. But most of these were small, accounting for 13 percent of corporate sector debt (Figure 10). In 2009, the share of firms with an ICR of less than one rose to 45 percent, accounting for 16.5 percent of total corporate debt. Preliminary data suggest that at end-2010, total debt-at-risk was slightly below pre-crisis levels. ${ }^{9}$

Figure 9. United Kingdom: Nonfinancial Corporates Funding
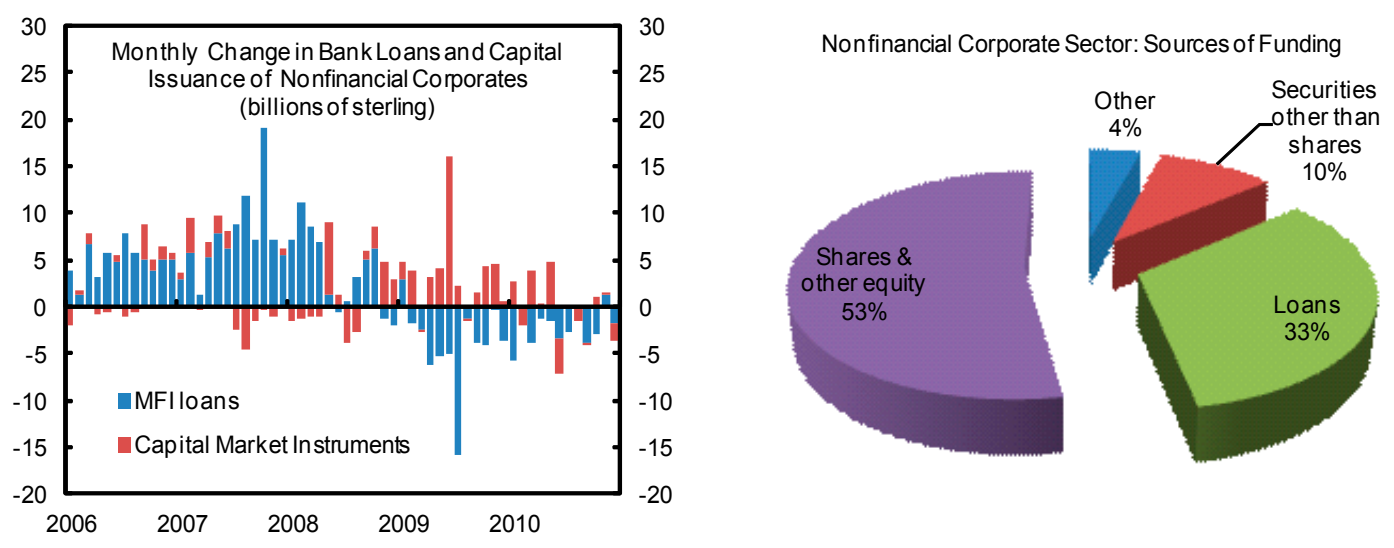

Sources: Bank of England; and Office for National Statistics.

Figure 10. United Kingdom: Debt at Risk of Nonfinancial Corporates
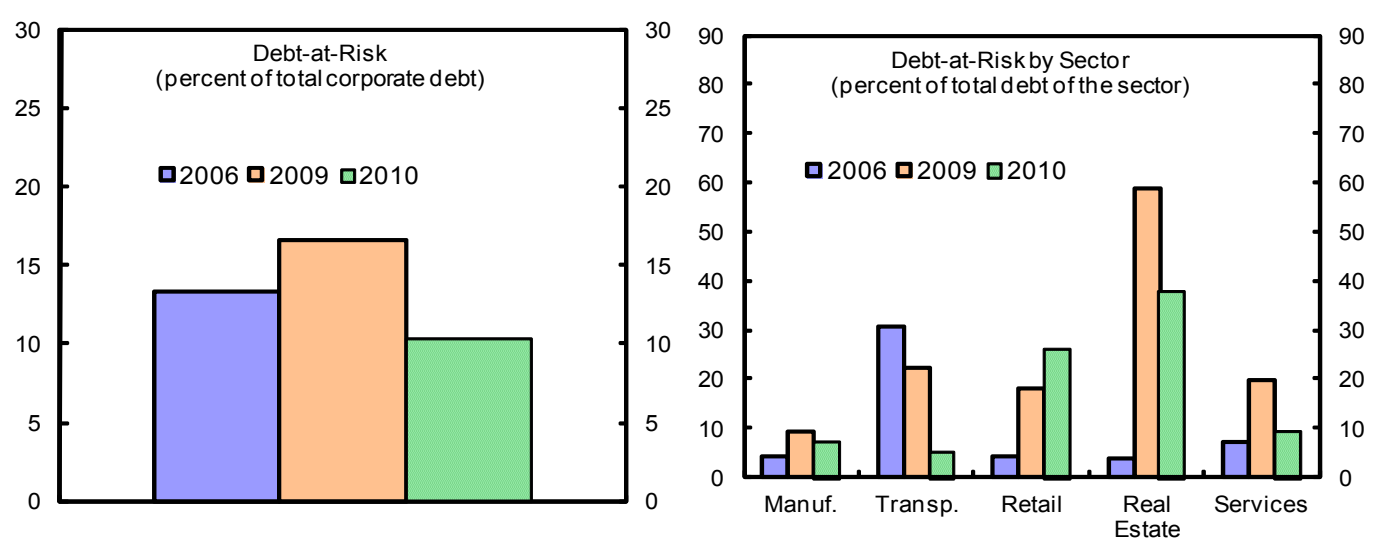

Sources: Worldscope; and IMF staff estimates.

\footnotetext{
${ }^{9}$ Data coverage is limited for 2010 , as not all firms posted financial results in Worldscope in time for this analysis. It is worth noting that due to data availability limitations, firm coverage in this analysis is smaller than in the firm-level analysis conducted at the BoE (only listed firms are included). This implies that the estimates in this analysis may not match similar estimates in BoE publications. Nonetheless, the thrust of our results and qualitative assessment are in line with the authorities' own analysis.
} 
29. These aggregate figures mask substantial variation across sectors:

- Many real estate firms had interest cover ratios close to one before the crisis, and so quickly crossed over the viability threshold when earnings suffered. By 2009, about 60-70 percent of total debt in this sector was at risk. Although this sector has since recovered somewhat, the share of debt-at-risk remains very high.

- $\quad$ Services and manufacturing were also hit by the crisis, albeit to a lesser extent. These sectors have recovered relatively well - the number of financially stressed firms has fallen significantly, and the share of debt-at-risk is now close to pre-crisis levels.

- $\quad$ The ongoing restructuring and deleveraging of transportation and communication translated into a continuous decline of debt-at-risk, which was barely dented by the crisis.

- In contrast, the debt-at-risk in retail kept increasing in 2010 relative to 2009. As a result, the share of distressed debt is still significantly above pre-crisis levels.

30. The hardest-hit sectors represent only about 20 percent of total corporate sector debt. Despite the increase of debt-at-risk, the total debt of the real estate, construction, and retail sectors is only about 20 percent of total (bank and nonbank) corporate debt, while the financial performance of the most leveraged sector at the beginning of the crisis (transportation and communication) strengthened significantly, pushing the aggregate level of debt-at-risk down.

\section{However, the hardest-hit} sectors represent a disproportionately high share of total bank claims on the corporate sector. Over 40 percent of total outstanding bank loans are to the struggling real estate sector. Moreover, real estate companies remain exposed to further declines in property prices.

Despite a modest rebound in commercial
Corporate(Bank and Non-bank) Debt by Sector

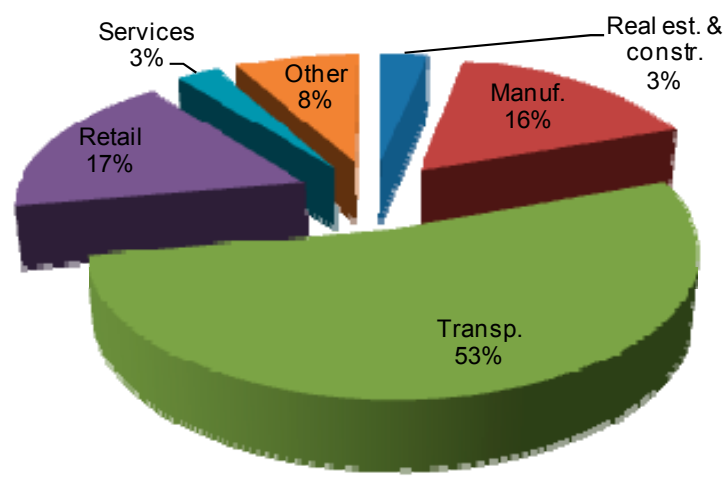

Sources: Worldscope; and IMF staff estimates.

Breakdown of Bank Lending to the Resident Nonfinancial Corporate Sector

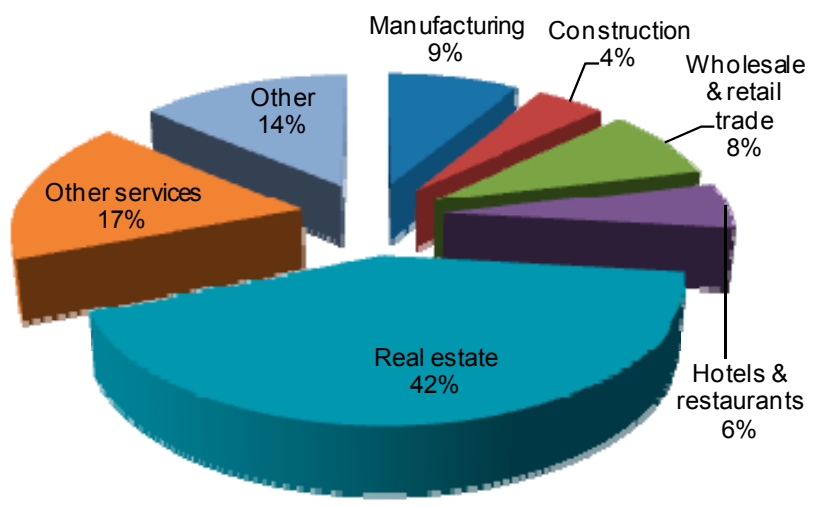

So urces: Worldscope; and IMF staff estimates 
property values, prices remain substantially below their peak, leaving a number of borrowers in negative equity or in breach of LTV covenants. So far, defaults have been contained by banks' forbearance and low interest rates. Lenders are exercising forbearance by ignoring breaches in LTV covenants, when borrowers continue to service their debt, and by evergreening loans. But a large share of loans is due to be refinanced in the next few years, and a large funding gap may arise if banks are less willing or able to roll over or restructure loans (Figure 11). In addition, commercial real estate (CRE) lending is very concentrated, with a few big banks accounting for a large share of the outstanding debt. Banks with large exposures would thus be hard-hit if economic and market conditions were to deteriorate sharply. Indeed, it is already the case that some lenders are facing arrears rates in excess of 30 percent in their CRE loan portfolios.

Figure 11. United Kingdom: Commercial Real Estate Sector
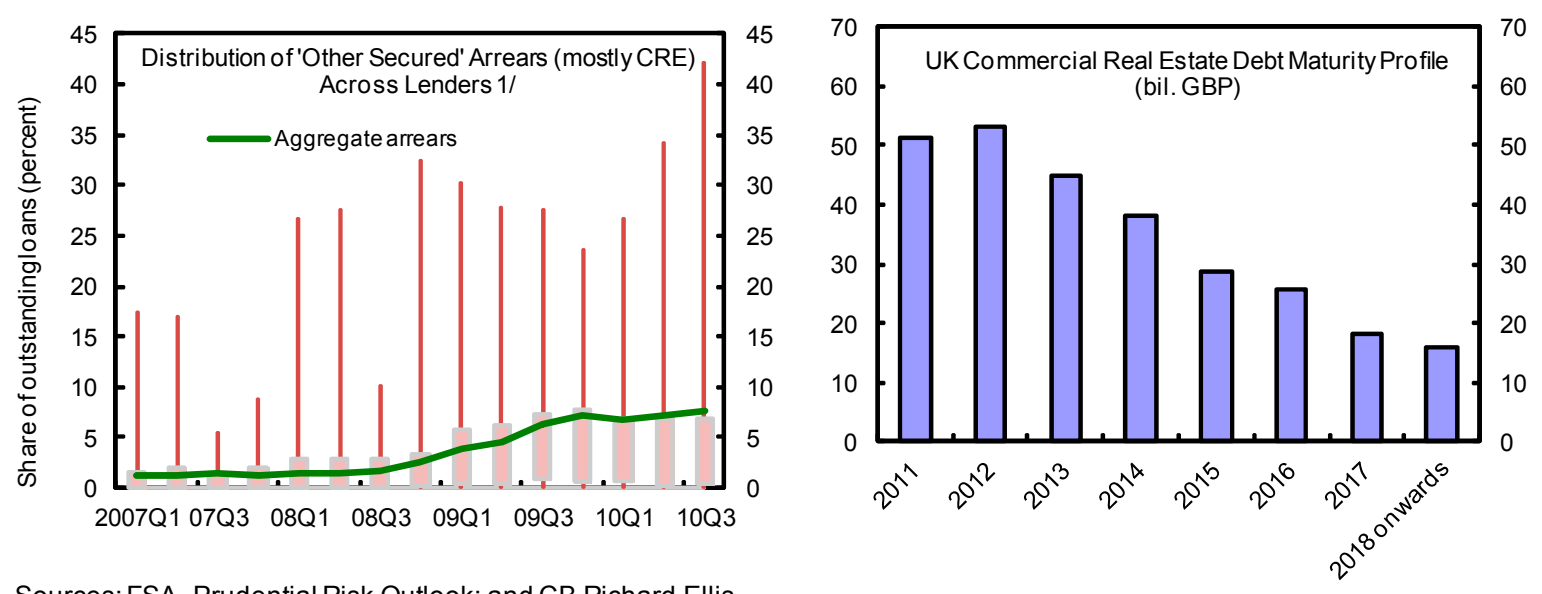

Sources: FSA, Prudential Risk Outlook; and CB Richard Ellis.

$1 /$ Data is for the 40 largest lenders. Spikes and bars show minimum, maximum and interquartile range.

\section{Contingent Claims Analysis of the Corporate Sector}

32. This section assesses the near-term prospects for the UK corporate sector. It attempts to answer two questions. First, how high is the risk of corporate sector defaults and what sectors are most vulnerable? Second, how large are the expected losses from defaults?

\section{To answer these questions, the note uses contingent claims analysis (CCA) to} estimate risk indicators for the nonfinancial corporate sector. The CCA approach combines balance sheet accounting information with equity prices prevailing in the financial market to obtain forward-looking measures of the risk of defaults and potential losses (Box 1). Under this approach, the risk of default is related to the probability that the value of a firm's assets will fall below the value of its liabilities. This in turn depends on two factors: firm leverage and uncertainty about the value of firm assets, which reflects the expected value of future profits.

34. Expected default probabilities increased markedly after September 2008, but have fallen back to near pre-crisis levels. The median expected one-year default 
probability for listed corporates in the UK (derived from Moody's KMV implied CDS spreads) increased from 0.3 percent in early 2008 to 2.8 percent in March 2009, an amount equivalent to a 15-standard deviation increase relative to the 2004-2008 average (Figure 12). At the height of the crisis, the risk of default exceeded 13.6 percent for a quarter of firms (seventy-fifth percentile series in the chart) and 30 percent for 10 percent of firms (ninetieth percentile series in the chart). The increase in default probabilities was triggered by the collapse of share prices and rising volatility as well as by tighter financing conditions and increased rollover risks. Default probabilities are now back to about 0.5 percent. Similarly, before the crisis (July 2007), only a small fraction of firms (accounting for less than 1 percent of total assets) had a default risk one year ahead that exceeded 1 percent. By January 2010, this proportion had increased to 10.5 percent, and it has narrowed to 3.25 percent in February 2011.

Figure 12. United Kingdom: Default Risk of Nonfinancial Corporates
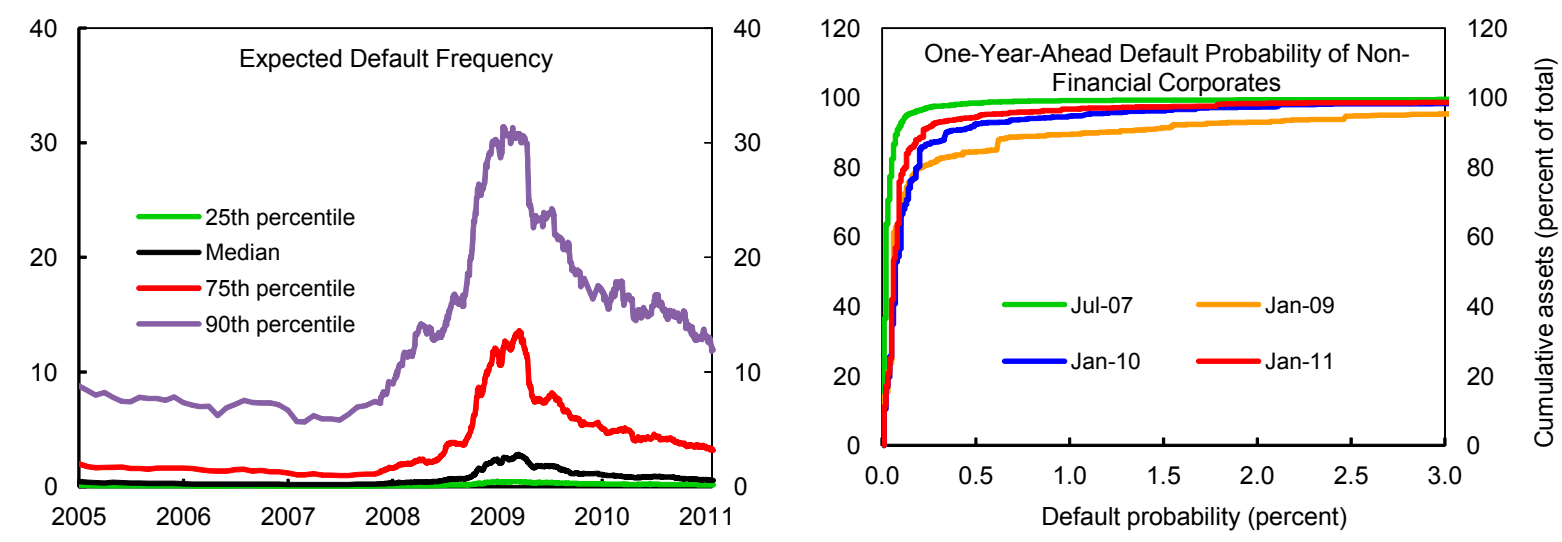

Source: Moody's KMV.

35. However, default risks vary widely across sectors. At the height of the crisis, default risk in some sectors (real estate, business products, leisure, and entertainment) increased sharply above the median for the overall corporate sector. Currently, these sectors continue to display higher default risk. In particular, the median real estate firm has a probability of default twice as large as the corporate sector as a whole. This is also the case for the leisure and entertainment sector, which was severely affected by the sharp decline in consumption, the slow turnaround during the recovery, and the cold winter weather. 


\section{Box 1. Contingent Claims Analysis (CCA)}

CCA is a risk-adjusted balance sheet framework where equity and risky debt of a corporation or financial institution derive their value from assets. In this framework, first proposed by Robert Merton (1973) and by Black and Scholes (1973), the total market value of assets of a firm or bank at any time is equal to the market value of equity and risky debt. Asset values are uncertain and, in the future, may decline below the point where debt payments on scheduled dates cannot be made. Debt is "risky" since there is a chance of default.

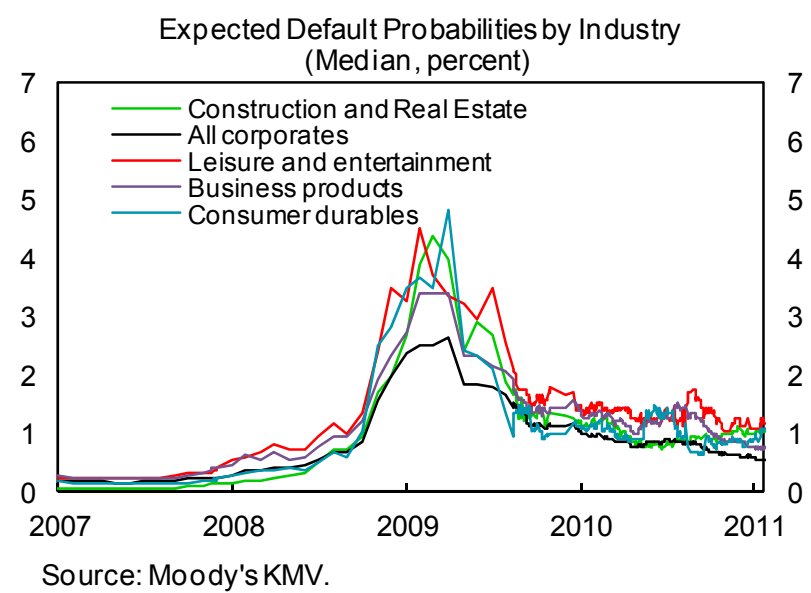

In CCA, equity and risky debt can be valued using finance techniques-i.e., valued using formulas for implicit call and put options - whose values are derived from assets, uncertainty of assets, and the promised debt payments. The value of risky debt is equivalent to the default-free debt minus the expected loss due to default. In CCA, the value of equity is computed as the value of an implicit call option, and the value of the expected loss due to default can be modeled with an implicit put option. The risk-adjusted balance sheet components can be calibrated by using forward-looking information from the equity market and information from the balance sheet to define the default barrier. The implied market value of assets and implied asset volatility are inferred from the market and balance sheet information; credit risk indicators, such default probabilities and credit spreads, can then be calculated. See Gray and Malone (2008) for a comprehensive analysis of the CCA framework.

Source: Moody's KMV.

36. Expected losses from corporate defaults appear contained relative to GDP. Based on default probabilities inferred from equity price data as of February 2011, the listed corporate sector is estimated to incur losses amounting to about 0.5 percent of GDP (Figure 13). This loss calculation is based on historical LGD rates, which, in the case of UK listed companies, is around 60 percent. With a lower rate of 20 percent, corporate losses could be just 0.2 percent of GDP. 
37. Corporate losses are expected to be the largest in the real estate sector. With higher-than-average default probabilities and historical LGD rates, construction and real estate is the most vulnerable sector, followed by business products and services (Figure 13). Overall, losses are expected to be larger in the nontradable sector. Breaking down the sample of listed companies by size shows that about three-quarters of losses are expected to fall on small- and medium-sized firms.

Figure 13. United Kingdom: Contingent Claims Analysis of the Corporate Sector
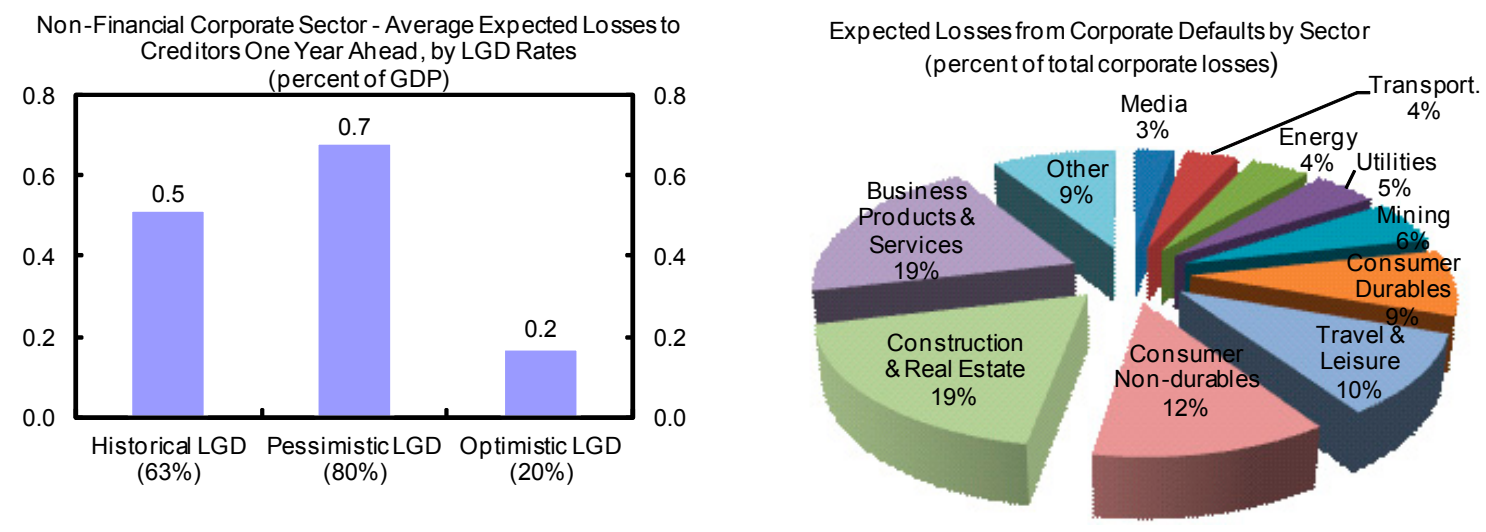

Sources: Moody's KMV; and IMF staff estimates.

\section{Sensitivity Analysis of the Corporate Sector}

38. This section examines how different types of shocks to the corporate sector would affect firms' viability. Firms where earnings before interest and taxes are less than interest payments due (i.e., ICR less than one) are considered unviable and their debt "at risk." The objective of this section is to analyze how many firms would face financial difficulties when hit by interest rate and profitability shocks. The results are expressed in terms of the debt of firms with an ICR less than one, or in other words, the debt-at-risk as a percent of total corporate sector debt. The sensitivity analysis uses firm-level data from Worldscope. As in the sensitivity analysis exercise for households, corporate balance sheets at end-2010 are the starting point for the analysis. The results that follow are based on a partial equilibrium exercise, and, as such, should be treated with caution.

\section{The results suggest that the corporate sector as a whole is vulnerable to profit} and interest rate shocks. Nevertheless, the overall picture is not alarming, as the increase in debt-at-risk is modest (Figure 14). In particular, a 300 basis points increase in interest rates would increase debt-at-risk by 3 percentage points, which is about the same increase observed during the crisis. In turn, a 30 percent decline in profits would increase debt-at-risk by 2 percentage points. The combined shock would have a more than proportional impact, pushing debt-at-risk by $6 \frac{1}{2}$ percentage points.

40. Macroeconomic shocks would exacerbate sectoral differences and further deteriorate the financial position of real estate companies, increasing the probability of 
default of those firms whose debt is at risk. The main concern is that the large portion of CRE firms that are already facing financial difficulties go into actual bankruptcy.

Furthermore, a big enough shock, such as the combined shock under consideration, would result in over three-quarters of real estate companies becoming unviable. This would have a significant impact on the banking sector, given that these firms make up a disproportionate share of total bank loans. Indeed, the most vulnerable firms (real estate) have mainly bank debt, while the stronger companies (manufacturing) have more nonbank debt. In contrast to what happened during the crisis, the retail sector appears relatively resilient to both interest rate and profit shocks, but the services sector would be particularly affected. The shocks would push the share of debt of firms with an ICR less than one to almost 50 percent from 10 percent currently. Some sectors, such as manufacturing, are more vulnerable to interest rate increases than to profit shocks.

Figure 14. United Kingdom: Sensitivity Analysis of the Nonfinancial Corporate Sector

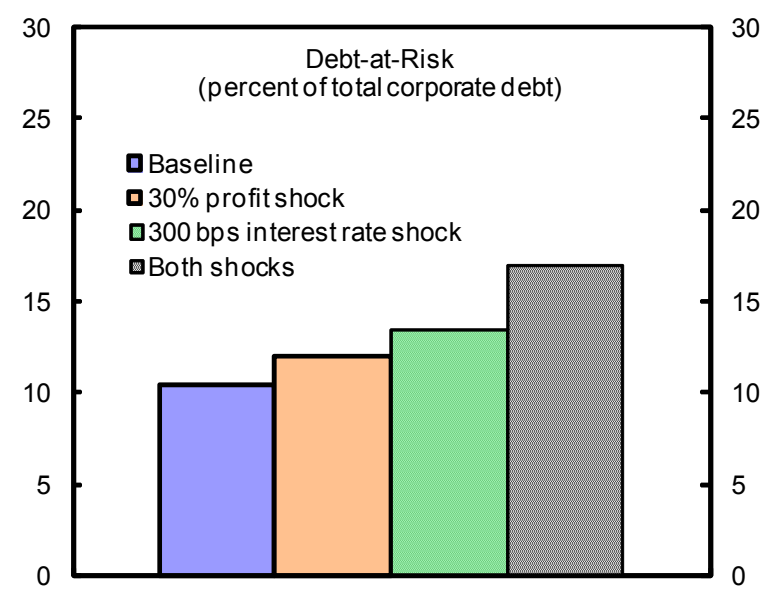

Sources: Worldscope; and IMF staff estimates.

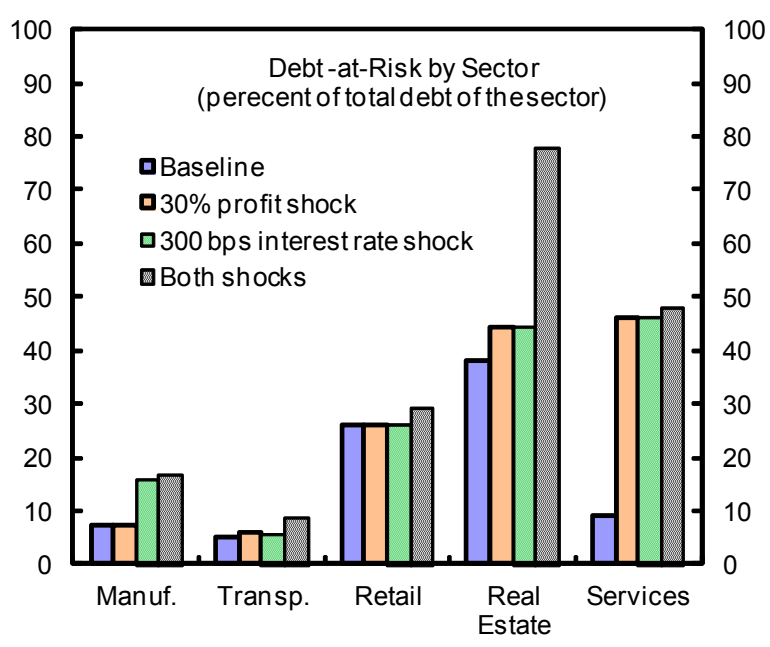

\section{Conclusion}

\section{UK households remain heavily indebted and vulnerable to shocks, but, on the} whole, the potential impact on banks from such shocks appears manageable. Though off its pre-crisis peak, household debt relative to disposable income remains high by both international and UK historical standards. This makes households vulnerable to income and interest rate shocks. Indeed, a very rapid normalization of interest rates to pre-crisis levels would have a large impact on household debt affordability, with negative implications for the economy. But the potential knock-on effect of these shocks on banks, albeit nonnegligible, would be mitigated, as most household bank debt is secured. Furthermore, low-income households, which are most sensitive to interest rate and income shocks, account for a relatively small proportion of bank mortgage lending. These results are based on a partial equilibrium exercise and hinge on the assumption that the underlying asset value is not 
affected by interest rate and income shocks and, as such, should be treated with caution. If house prices fell simultaneously, banks' LGD would be much higher, as discussed below.

42. At a more granular level, however, there are important vulnerabilities. First, while unsecured debt is a relatively small share of bank lending, absolute losses from unsecured debt have so far surpassed losses from mortgage defaults, which have remained low relative to both those in the US and to previous crises. Since low-income households account for a relatively large share of banks' unsecured lending, bank losses could jump if interest rates were to increase rapidly. Second, since the ratio of house prices-to-income remains significantly above the historical average, further sharp declines in house prices could have a major impact on household net worth, and, thus, the potential to inflict significant losses on banks. Finally, some segments in the mortgage debt market appear vulnerable and negative shocks would especially affect borrowers with high loan-to-value ratios and buy-to-let loans.

43. The corporate sector weathered the crisis relatively well and leverage has subsequently declined and profitability strengthened. The increase in the number of company liquidations during the crisis was moderate compared to previous crises and has been declining since late 2009, supported by the low interest rate environment. The sector as a whole appears relatively resilient to profitability and interest rate shocks. Contingent claims analysis, which combines balance sheet and equity market information to obtain forwardlooking measures of the risk of default, also suggests that losses from corporate defaults one year ahead are expected to be limited.

44. One important exception is the CRE sector. Both sensitivity analysis and contingent claims analysis suggest that macroeconomic shocks would affect disproportionately this sector, which is still recovering from the impact of the crisis. Although the share of this sector in total corporate sector liabilities is relatively contained, it represents almost half of total bank loans to the nonfinancial corporate sector, and, thus, is an important potential risk for the banking system. Furthermore, a large share of loans is due to be refinanced in the next few years, and a large funding gap may arise if banks are less willing or able to roll over or restructure loans. Moreover, declines in CRE prices could push a number of CRE companies over the edge-despite a recent rebound, CRE prices remain substantially below their peak, with many borrowers in negative equity or in breach of LTV covenants.

45. Financial distress and credit risks may be larger than suggested by the headline figures of write-offs and liquidations. Two important factors are at play: lender forbearance and concentration of risks in some banks. Lenders forbearance has played a material role in containing defaults to date, particularly in the CRE sector, and may be disguising the true extent of risks. Lenders are exercising forbearance by ignoring breaches in LTV covenants when borrowers continue to service their debt and by evergreening loans. While some degree of restructuring is acceptable for a reasonable period of time, it is unclear how widespread 
this practice is and whether it is masking true impairment, and whether restructured assets are properly accounted for and monitored. In addition, CRE lending is very concentrated, with a few big banks accounting for a large share of the outstanding debt. Banks with large exposures would thus be hard-hit if economic and market conditions were to deteriorate sharply.

46. Furthermore, banks are exposed to the household and corporate sectors not just through loan portfolios but also through holdings of securities. In the latter case, markets have tended to react much more quickly to changes in risk factors - changes in interest rates, unemployment, and house prices - well before these factors have significantly affected loan portfolios. This was, in fact, a key feature of the recent crisis, with its high impact on residential and commercial mortgage-backed securities and consumer asset-backed securities.

47. Finally, credit risks may also arise from banks' exposures to non-UK household and corporate sectors. In particular, some banks have significant exposures to the residential and commercial property markets in the US and some Asian countries. Interest rate and house price developments in these markets could have implications for major UK banks' financial positions. 


\section{REFERENCES}

Bank of England, (2010), Financial Stability Report, December 2010, Issue No. 28.

, (2011a), Credit Conditions Survey, 2011 Q1 and 2011 Q2.

, (2011b), Financial Stability Report, June 2011, Issue No. 29.

Beer, C., and M. Schurz, (2007), "Characteristics of Household Debt in Austria: Does Household Debt Pose a Threat to Financial Stability?" Monetary Policy and the Economy, Oesterreichische Nationalbank (Austrian Central Bank) (2), pp. $58-79$.

Black, F., and M. Sholes, (1973), "The Pricing of Options and Corporate Liabilities," Journal of Political Economy, Vol. 81, No. 3, pp. 637-654.

Financial Services Authority, (2011), Prudential Risk Outlook, Financial Services Authority (London).

Grey D., and S. Malone, (2008), Macrofinancial Risk Analysis, John Wiley and Sons (New York).

Karasulu M., (2008), “Stress Testing Household Debt in Korea,” IMF Working Paper $\mathrm{WP} / 08 / 255$.

May, O., M. Tudela, and G. Young, (2004), "British Household Indebtedness and Financial Stress: A Household-Level Picture," Bank of England Quarterly Bulletin, Winter 2004.

Merton, R. (1973), “Theory of Rational Option Pricing,” Bell Journal of Economics and Management Science, Vol. 4, pp. 141-83.

Nielsen M., S. Pezzini, K. Reinold, and R. Williams, (2010), "The Financial Position of British Households: Evidence from the 2010 NMG Consulting Survey," Bank of England Quarterly Bulletin, 2010 Q4.

Sá, F., P. Towbin, and T. Wieladek, (2011), "Low Interest Rates and Housing Booms: the Role of Capital Inflows, Monetary Policy, and Financial Innovation,” Bank of England Working Paper No. 411. 